Illinois State University

ISU ReD: Research and eData

Theses and Dissertations

$3-22-2017$

\title{
An Examination of The Evolution Of Racially Biased Pretextual Investigatory Stops And Their Legitimacy In Policing
}

Brett A. Lacey

Illinois State University, balacey@ilstu.edu

Follow this and additional works at: https://ir.library.illinoisstate.edu/etd

Part of the Criminology Commons, and the Criminology and Criminal Justice Commons

\section{Recommended Citation}

Lacey, Brett A., "An Examination Of The Evolution Of Racially Biased Pretextual Investigatory Stops And Their Legitimacy In Policing" (2017). Theses and Dissertations. 760.

https://ir.library.illinoisstate.edu/etd/760

This Thesis is brought to you for free and open access by ISU ReD: Research and eData. It has been accepted for inclusion in Theses and Dissertations by an authorized administrator of ISU ReD: Research and eData. For more information, please contact ISUReD@ilstu.edu. 


\title{
AN EXAMINATION OF THE EVOLUTION OF RACIALLY BIASED PRETEXTUAL INVESTIGATORY STOPS AND THEIR LEGITIMACY IN POLICING
}

\author{
Brett A. Lacey
}

\section{Pages}

This thesis examines the use of tactics originally purposed as a component of the Drug Enforcement Agency's Operation Pipeline and their evolution since their creation in the 1980's. The paper provides a history of investigatory policing stops regarding the argument of Epp et al. (2014) that primarily relied on Police Chief magazine and Remsberg's Street Survival. Epp argues that the methods used in investigatory stops are an invasion of privacy, use racial profiling, and have proliferated from a tactic used in the war on drugs to combat drug trafficking to a routine day-to-day policing tactic. Through the use of a narrative review this paper will provide a detailed illustration of investigatory stops, the evolution of techniques involved in these stops, court decisions effects on enforcement policies, proliferation of investigatory stops, and racial disparities investigatory stops.

KEYWORDS: Investigatory Stops, Racial Profiling, Fourth Amendment, Policing, Interdiction, Trafficking, Seizure 


\title{
AN EXAMINATION OF THE EVOLUTION OF RACIALLY BIASED PRETEXTUAL INVESTIGATORY STOPS AND THEIR LEGITIMACY IN POLICING
}

\author{
BRETT A. LACEY
}

\author{
A Thesis Submitted in Partial \\ Fulfillment of the Requirements \\ for the Degree of \\ MASTER OF SCIENCE \\ Department of Criminal Justice Sciences \\ ILLINOIS STATE UNIVERSITY
}


(C) 2017 Brett A. Lacey 


\section{AN EXAMINATION OF THE EVOLUTION OF RACIALLY BIASED PRETEXTUAL INVESTIGATORY STOPS AND THEIR LEGITIMACY IN POLICING}

BRETT A. LACEY

COMMITTEE MEMBERS:

Michael Gizzi, Chair

Ralph Weisheit

Shelly Clevenger 


\section{ACKNOWLEDGMENTS}

I would like to thank my thesis chair, Dr. Gizzi, for all the assistance and answering my endless stream of questions throughout this process. I would also like to thank both, Dr.

Weisheit and Dr. Clevenger for their time to provide supervision and feedback. Lastly, my

fiancée Kate as she has sacrificed a substantial amount of time and effort compensating for my

lack of contributions with our family throughout the course of this study.

B. A. L. 


\section{CONTENTS}

Page

ACKNOWLEDGMENTS

CONTENTS

TABLES

CHAPTER I: INTRODUCTION 1

CHAPTER II: LITERATURE REVIEW

Court Cases' Impact on Pretextual Investigatory Stops 5

Belton and Operation Pipeline $\quad 10$

$\begin{array}{ll}\text { Operation Pipeline } & 10\end{array}$

Whren, Pretextual Stops, and Racial Profiling 13

Investigatory Stops and the War on Drugs $\quad 19$

The Use of Profiling in Investigatory Stops $\quad 21$

Anatomy of an Investigative Stop $\quad 27$

Procedural Justice and Investigatory Stops $\quad 29$

Civil Asset Forfeiture $\quad 30$

Law Enforcement Justification of Pretextual Investigatory Stops 31

CHAPTER III: RESEARCH QUESTION AND DESIGN 33

Examining the Research Question $\quad 33$

Defining Narrative Review $\quad 34$

$\begin{array}{ll}\text { CHAPTER IV: RESULTS } & 37\end{array}$

Operation Pipeline, The War on Drugs, and the Origins of Investigatory Stops 37

Lt. Kirk Simone: Operation Pipeline Passenger Vehicle Drug Interdiction Manual 40

Remsberg: Tactics for Criminal Patrol $\quad 42$

Leadership Approval and the Discovery of Aggressive Patrol 49

Racial Profiling Litigation and Opposition $\quad 54$

Haines: Inroads: A Working Solution to America's War on Drugs

John Eagleson: It's 4:20 Somewhere $\quad 61$

Switch from Profiles to Indicators 63

Investigatory Stops, Operation Pipeline, and Drug Interdiction Schools 67

$\begin{array}{ll}\text { CHAPTER V: DISCUSSION } & 69\end{array}$

$\begin{array}{ll}\text { CHAPTER VI: CONCLUSION } & 73\end{array}$

$\begin{array}{ll}\text { REFERENCES } & 74\end{array}$ 
APPENDIX B: LIST OF SOURCES ANALYZED 


\section{TABLES}

Table

1. Indicators in Early Manuals

2. Indicators in Recent Manuals
Page

64

66 


\section{CHAPTER I: INTRODUCTION}

An abundance of traffic violations exist that can be grounds to pull over any motorists. However, not all motorists are treated the same after the commencement of a traffic stop. When an officer observes a traffic violation the ensuing stop can be based solely on the traffic violation and result in only a ticket or warning, or can be an investigative stop where the minor traffic violation is used as justification to further investigate the motorist to search their person, search their vehicle, seize their vehicle, or additional criminal sanctions. Investigatory stops are largely supported by courts, policymakers, and law enforcement, but a growing disapproval exists amongst academia and the minorities that are mainly targeted in these stops. Disapproval and criticism regarding pretextual investigative stops increased dramatically after the Whren $v$. United States (1996) decision (Johnson 2016).

During instances when a traffic violation has occurred the officer has objective probable cause to make the traffic stop. This differs from a "Terry Stop," which occurs when a motorist or pedestrian is briefly detained based on reasonable suspicion of criminal activity. When a traffic stop is conducted as an investigatory stop, the officer or law enforcement agent's basis for conducting the stop is objective probable cause from observing a motor vehicle or traffic violation, though the traffic stop is only pretextual or an excuse to conduct a criminal investigation where no probable cause exists. The use of a violation of a minor traffic offense as a pretext for a criminal investigation is known as an investigatory stop. In Whren, the Supreme Court held that a stop of a motor vehicle was not a violation of the Fourth Amendment's prohibition of unreasonable searches and seizures as long police had probable cause to think that a traffic violation existed - even if law enforcement utilized the violation pretextually to stop the vehicle based on the race of its occupants (Gamrath 1997). The Court held that law 
enforcement's underlying motivation was irrelevant, and as long as objective probable cause of a traffic violation existed, the stop was reasonable. Claims of racial bias were ignored under the argument that such concerns should be raised under the $14^{\text {th }}$ and not the $4^{\text {th }}$ amendment.

Investigatory traffic stops originated as a component of the war on drugs, but since the late 1990s, law enforcement discovered they could rationalize these stops as "good police work" as result of an increase in arrests and seizures. Pretextual investigatory stops are considered by law enforcement to be one of "policing's most effective crime fighting tools" (Epp et al 2014). To fully comprehend that law enforcement officers are attempting to disguise the institutionalized racist beliefs and procedures that occur surrounding investigatory stops it is necessary to examine the evolution of the investigatory stop, the racial disparities in investigatory stops, and the manipulation of legislation to allow pretext stops.

Though nearly all victims of pretextual investigatory stops find issue with the practice, the use of pretextual investigatory stops on minorities is the largest portion of the problem. Though these stops were originally intended as a deterrent against drug trafficking near the border, investigatory stops became a nationwide phenomenon as police discovered these stops did not have to remain limited to drug trafficking (DEA 1985). Once law enforcement realized the benefits of increased arrests, seizures, and asset forfeiture they began taking steps to implement investigatory stops as a widespread practice through training, funding, and the education of officers nationwide.

One must first examine the criteria of a traffic stop versus a pretextual investigatory stop to differentiate between them. A routine traffic stop occurs when a police officer observes a motorist who is committing a traffic violation and pulls them over with the main intention of issuing a ticket or a warning to the motorist for said violation. A pretextual investigatory stop 
occurs when the officer determines that a motorist is suspicious and then uses any traffic infraction, no matter how minute, as justification to pull the motorist over and further investigate for further violations or possible criminal charges (Lawton 2016).

Minor offenses which could be used as justification for a pretextual investigatory include, but are not limited to: having a license plate light out, a turn signal being on too long, a wobbly wheel, a bouncing tire, a bald or bulging tire, a missing mirror, a brake light out, a blinking headlight, having the wrong bumper height, lack of mud flaps, a cracked windshield, parking violations, weaving within one's lane, a prolonged stop or stop for no reason, police knowledge of a warrant, recognizing they driver has a suspended license, running a registration check and license suspension check, or finding a warrant while checking registration. Reasonable suspicion is not required for these violations (Wallentine 2009). Officers conducting investigative stops are not interested in writing traffic citations, their goal is to "go beyond the ticket" and attempt to find criminal charges, warrant or seizures (Sweeney 1996).

In Pulled Over, Epp et al (2014) present the argument that police transformed investigatory stop methods, including racial profiling, used in the war on drugs into a routinely used day to day practice in policing. To form this argument Epp mainly relied on data from Police Chief magazine and Remsberg's (1995) Tactics for Criminal Patrol: Vehicle Stops, Drug Discovery, and Officer Survival. Epp et al. argue police have transformed racially biased pretextual investigatory stops by reconditioning them as "good police work" and made investigatory stops a day to day policing practice. To construct this argument, Epp et al. draw from a Police Chief (1996) article stating: "proactive traffic enforcement is an effective strategy to protect the public from the devastation caused by drug abuse, street and highway trafficrelated death and injury, illegal trafficking in and possession of weapons, and the continued 
freedom of fugitives, as well as to otherwise promote and maintain an orderly and law-abiding society (p.144)." This statement is an accurate depiction of the manner in which police justify investigatory stops as "good police work" to address numerous criminal issues and not a racially biased infringement of constitutional rights and an invasion privacy. Epp et al. illustrate that police are aware of the use of profiling in conducting investigatory stops and attempt to conceal its use by quoting Remsberg (1995); “you must look for the right people, but not just minorities though it is most effective, officers rarely utter the "P" word except amongst themselves (p.45)." This statement, out of a policing manual, acknowledges that officers are not only aware that they are targeting minorities, but that they develop strategies to conceal the usage of racial profiling under different names. This thesis will further explore the argument of Epp et al. by answering the research question: has the practice of pretextual investigatory stops evolved from a tactic specifically intended for the war on drugs to a routine day to day practice using techniques that are supported in policing literature and police culture under the false premise of "selling" an invasion of motorist privacy as good police work? Using a narrative review and quantitative content analysis this thesis will explore data from policing manuals, policing magazines, literature from drug interdiction training programs, court decisions, and academic journals to see if Epp et al.'s argument stands up to scrutiny.

To consider if the criminal justice system as well as law enforcement are attempting to disguise the institutionalized racist beliefs and procedures that occur surrounding investigatory stops it is necessary to examine the history of court cases involving investigatory stops, the evolution of the investigatory stop, the racial disparities in investigatory stop occurrence and practices, and the manipulation of legislation to commit pretext stops. 


\section{CHAPTER II: LITERATURE REVIEW \\ Court Cases’ Impact on Pretextual Investigatory Stops}

The Fourth Amendment and rights concerning search and seizure have been the subject of numerous court proceedings heard by the Supreme Court. The following were major decisions that have had an impact or were the foundation for and later cases that would impact the use of investigatory stops. The Supreme Court made the automobile exception rule in Carroll v. United States (1925). In forming this warrant exception, the Court found that if law enforcement were to wait for a warrant on an automobile the car could simply drive off and no longer contain evidence that may have been found while conducting a search. In Carroll, evidence from a search was allowed even though the stop was conducted on the basis of a four-month-old tip that the vehicle was being used for bootlegging. This finding was the beginning of law enforcement being able to conduct searches on vehicles without a warrant. The Court in Carroll held that if the officer had probable cause that contraband was present in the vehicle, a complete search of the vehicle could be conducted, without a warrant. In United States v. Lefkowitz (1932), the Supreme Court held that an arrest may not be used as a pretext to search for evidence. Under this doctrine, evidence found from a pretext stop was inadmissible and excluded to deter police misconduct and rewarding officers for pretexts stops (Gamrath 1997).

Another early precedent that allowed tips to be used to conduct stops can be found in Draper v. United States (1959). In Draper, the Court held that hearsay could be used for probable cause, but not as a determinant of guilt. In this case, an informant provided the information that heroin would be shipped via train and provided a hearsay description of the suspect. The suspect was then arrested at the station of destination and the heroin seized. Though the suspect was apprehended, the informant died prior to testimony being heard. Both Draper 
and Carrol illustrate the basis for the low standard of probable cause which transformed into an essential part of a crime control jurisprudence that shows leniency regarding police behavior.

Reasonable suspicion occurs when there could be a presumption that a crime has, is, or will be committed. It is a reasonable, not logical belief based on facts or circumstances. It is more than a guess, but less than probable cause. Probable cause is a logical belief that is supported factually and circumstantially that a crime has, is, or will be committed (Pulliam 1994). Reasonable suspicion consists of a combination of the following factors: time of day, dress, suspicious conduct, crimes in the area, location, known history, nervousness, unprovoked flight, walking away, wanted flyers, and collective knowledge of multiple officers. Even if a stop yields an innocent explanation reasonable suspicion still can exist (Wallentine 2009). Reasonable suspicion for a traffic violation becomes interchangeable with reasonable suspicion to stop the driver and conduct an investigation with the intention of finding a more severe crime (Levit 1996).

The Court's 1968 decision in Terry v. Ohio was a critical step in the expansion of police discretion and crime control. The finding in Terry was far-reaching and remains cited and relevant nearly fifty years later. The Court held that law enforcement could conduct a limited stop for a limited purpose if there was a reasonable articulable suspicion of wrongdoing. If an officer had a reasonable suspicion that a crime was committed or soon would be committed, they could detain the suspect to see if the suspicion was justified and allow law enforcement to conduct a limited search of the detainee, if the officer feared for his or her safety. This allowed for a pat down resulting from brief on the street questioning. These pat downs came to be known as "Terry Stops" or stop and frisks. In his dissent, Justice Douglas argued that this finding gives 
the officer a power greater than the magistrate and that law enforcement were being given too much power.

When probable cause doesn't exist, police officers attempt to acquire consent by persuading motorists to allow them to search the vehicle (Banks 2016). When observing a traffic violation, the officer has probable cause to conduct a stop due to the violation which is a higher standard of proof than reasonable suspicion, meaning the stop is not a Terry Stop. The observed violation makes an objective stop where probable cause exists. However, when the officer uses the traffic violation as a pretext for a criminal investigation, it becomes a pretextual investigatory stop, which the equivalent of a vehicular Terry Stop with a "legal" definition of a probable cause traffic violation (Gizzi \& Clark 2016)

Banks (2016) argues that the Fourth Amendment was intended to offer protection against practices such as Terry Stops. The exemption of voluntary consent cannot be used by police to create their own causes of articulable reasonable suspicion to pull over or stop citizens at their own discretion. The justification given for this practice is that it is a valuable tool that can be used by police officers to stop a crime before it has been committed. This expansion of police power nullifies the previous standard of probable cause or the necessity of a warrant. Terry Stops soon became used universally and nationwide due to the subjective nature of the stops allowing them to easily be expanded into different situations and removing the need for warrants or probable cause (Hecker 1997). The use of reasonable suspicion as the standard of proof removed mandatory objectivity from stops and lowered the threshold for the standard of proof. Law enforcement has manipulated the use of Terry Stops to allow free rein to detain any citizen they desire. The use of reasonable suspicion as the standard has also been applied to motor vehicles in such instances as investigatory stops. 
In Pennsylvania v. Mimms (1977) the Court held that officers may order the driver to get out of the vehicle without violating the Fourth Amendment after the vehicle has been detained for a traffic violation (Rutledge 2005). This allows for the officer to perform a "sensory pat down" of the subject when the exit the vehicle (Remsberg 1995).

The Supreme Court finding of the 1960s operated on more of a due process jurisprudence. After police were repeatedly tested during the turbulent social times of the $1960 \mathrm{~s}$ which involved war protests and the Civil Rights movement, the1970s and 1980s replaced legal precedents that favored the accused and replaced them with an expanded police power, limited the exclusionary rule, and provided numerous exceptions to the Fourth Amendments warrant requirements. These factors, combined with a Supreme Court comprised of mainly conservative minded Justices who supported crime control made prodefendant findings a rare occurrence. Through findings that leaned towards the jurisprudence of crime control the court assisted police in waging the war on drugs, especially regarding techniques used in vehicle searches (Gizzi \& Curtis 2016)

The following cases illustrate the shift from due process to crime control. In Chimel v. California (1969) the Court found the search incident to arrest doctrine. This doctrine allowed law enforcement to search the person of the arrestee and areas with in their reach or wingspan. Chambers v. Maroney (1970) set the precedent that law enforcement could seize a motorist's vehicle and search it at the police station, thereby expanding the scope of beyond on-the-streetvehicle searches.

Delaware v. Prouse (1979) allowed for suspicion-less roadside checks for license and registration. This practice violates a reasonable expectation of privacy. This finding was expanded in Michigan v. Sitz (1990) with the Court ruling to allow roadside sobriety checkpoints 
to force all motorists to interact with police. The Court further viewed the intrusion of individual liberty as minimal in comparison to the state's substantial interest in preventing drunk driving. Though it would not have the impact of Terry on stops, NYv. Belton (1981) provided police with a standing rule for searches incident to arrest in cases where the arrest occurs in a vehicle. The Court in Belton found that the wingspan or reach provision in Chimel was difficult to enforce due to the subjectivity of the wingspan differential of motorists. The finding allowed police to search the entire passenger compartment, any containers, just not a locked glove compartment or trunk. The precedent from Belton can be applied to any arrest. Though the finding stated that the reasoning was to prevent the driver from committing further offenses by being capable of grabbing a weapon or further evidence, the Court ignored the fact that if the driver was no longer a risk and no longer has access to the vehicle after arrest, the drive no longer poses a threat. The Belton rule meant that if there was any arrestable offense police could search entire passenger compartment on a pretextual stop. Probable cause of criminal activity was no longer needed after the traffic offense. If the officer simply arrested the motorist for the traffic offense, the entire passenger compartment of the vehicle could be searched under Belton. While this did not include the trunk or a locked glove box (as the automobile exception would), Belton made it far easier for law enforcement to search vehicles in the hopes of finding evidence or contraband. The Drug Enforcement Agency recognized the value of this type of search. As early as 1984 they began training law enforcement officers on how to profile vehicles driven by drug couriers and use traffic offenses as a pretense for investigatory searches (Gizzi \& Douglas 2016).

A significant movement in the shift toward crime control jurisprudence began with the narrowing of the exclusionary rule. The exclusionary rule prevents the government from using 
evidence gathered from an unreasonable search and seizure regarding the Fourth Amendment (Cornell 1992). The Court determined that the rule was only to deter police misconduct, though their underlying intentions may have been to expand police discretion. Justice Powell found that the exclusionary rule was not a constitutional right, but was a judicial remedy. In United States v. Leon (1984) the Supreme Court modified the exclusionary rule by creating the good-faith exception, allowing for use of evidence found in an unreasonable search, if the officer believed that the search was valid. The Court further determined that suppressing evidence had no deterrent effect. The exclusionary rule would only be used sparingly as a remedy when there was evidence of police misconduct. This finding allowed for police to use evidence even in unreasonable stops if the officer believed the stop was valid.

\section{Belton and Operation Pipeline}

The Belton rule, which modified the findings in Chimel, was then applied and adapted as a component of Operation Pipeline which was rapidly becoming a routine practice. The modern story of widespread racially biased policing begins with the Drug Enforcement Agency's (DEA) Operation Pipeline, which starting in 1984 trained 25,000 state and local police officers in 48 states to recognize, stop, and search potential drug couriers. Part of that training included considering the suspects' race. In 1985, the Drug Enforcement Agency (DEA) introduced a racially biased drug courier profile designed as a drug-fighting template in its war on drugs program dubbed "Operation Pipeline (Cole 2000)."

\section{Operation Pipeline}

Operation Pipeline brought forth the beginnings of highway drug interdiction and profiling. Even this early into the wider application of investigatory stops law enforcement concealed and denied racial profiling. Law enforcement targeted border area drug traffickers and 
found that many had similar characteristics, traits, methods, and tendencies (DEA 1985). Agents and officers constructed interview techniques that were highly effective in drug interdiction. The success of these techniques became Operation Pipeline after the successful use on drug trafficking. Training programs and exercises were developed that focused on law, policy, and prosecution as well as shared traits, including race, among traffickers (DEA 1985). This was the beginning of manipulating traffic stops to produce the desired results while staying within the law. Operation Pipeline involved the excuse of traffic violations to make arrests on Hispanics and Blacks that fit a profile (Harris 1999). Operation Pipeline started in 1984 in an effort that focused on teaching officers to identify smugglers and use the pretense of traffic stops to investigate. Race was a major factor in profiling used in Operation Pipeline.

In 1985, DEA Administrator Francis Mullen drafted a memo ordering a more cohesive and centralized approach to interdiction, the following policy "on policy, strategy, and tactical levels, your cooperation with other agencies in all current and future DEA efforts is hereby ordered." This memo forced the cooperation of local and state law enforcement which included making pretextual investigatory stops. The same year, the Florida Department of Highway Safety and Motor Vehicles issued guidelines for the police on common characteristics of subjects involved in drug trafficking. The guidelines included being suspicious of rental cars, "scrupulous obedience of traffic laws," drivers with an abundance of jewelry, and "ethnic groups associated with the drug trade" (Harris 1999). By targeting those who scrupulously obeyed traffic laws, police were given approval to pull over any motorist. The usage of the phrase "ethnic groups associated with the drug trade" also provided law enforcement with permission to racially profile. 
The modern utilization of profiling was largely influenced by Florida highway patrol officer Bob Vogel. In the early 1980s, Vogel pulled over numerous vehicles on a "hunch," due to not liking their appearance or the way they made him feel. He could seize large amounts of drugs and weapons through the use of these methods. Courts found that this usage of profiling was unconstitutional as they resulted in "unreasonable searches and seizures (Webb 1999). Due to the effectiveness of the techniques, Vogel was unwilling to cease their use and continued to pull over suspicious drivers for minor traffic violations to search their vehicles. The use of the minor traffic violation loophole led to the creation of Operation Pipeline. Operation Pipeline's tactics are presently used in 301 agencies throughout 48 states (Kamulu 2016).

The obvious problems with Operation Pipeline are that many of these police searches come up with nothing and that most police officers seem to consider minorities to be suspicious looking. Operation Pipeline targeted cars on backroads, rental cars, near border on interstate highways, trucks, and vehicles being driven by people of color (Cole 2000). Sheriff Vogel and his deputies used hundreds of minor violations from the Florida vehicle code, using rarely enforced laws such as burned out license plate lights, off center headlights, obscure registration stickers, cracked windshields, and other violations dating back to the period of the horseless carriage (Webb 1999). Although they are scarcely referred to as pretextual investigatory stops in policing literature, the use of minor traffic violations to produce criminal investigation on motorist used in Operation Pipeline are the epitome of what constitutes an investigatory stop.

On the same Interstate 95 in Florida, where Operation Pipeline originated, seventy five percent of the motorists and traffic violators along one stretch of the highway were white, but eighty percent of the searches were of minorities (Cannon, 1999). This problem is not isolated to Interstate 95, but the Operation Pipeline method of racial profiling is now commonplace along 
nearly every highway in America. In New Jersey, seventy seven percent of motorists searched on the turnpike were black or Hispanic, even though sixty percent of those stopped were white (Taylor, 1999). Ninety percent of the people arrested by the CHP's Pipeline units during a twoyear period were minorities (Webb, 1999).

Jurisdictions developed a variety of profiles in response to Operation Pipeline. For example, in Eagle County, Colorado, motorists who had fast food wrappers in their vehicle, outof-state plates, and dark skin were profiled (Kamulu 2016). Delaware targeted minority men carrying pagers and wearing gold jewelry. Delaware's drug courier profile commonly targeted young minority men carrying pagers or wearing gold jewelry. And according to the American Civil Liberties Union (1999), Florida profiled rental cars, disobedience of all traffic laws, drivers wearing gold, those who do not "fit" their vehicle, and ethnic groups associated with the drug trade. In Whren v. United States (1996) the Court was given the opportunity to directly address the use of pretextual investigative stops and racial profiling.

Whren, Pretextual Stops, and Racial Profiling

Whren establishes that pretextual traffic stops, in which officers use traffic violations as a pretext to investigate other criminal activity, are "reasonable" under the Fourth Amendment. This decision provides a strong incentive for law enforcement to contrive justifications other than race for investigatory stops even if race was the actual reason for the stop (Johnson 2016). Whren $v$ United States required neither reasonable suspicion or probable cause to believe they were engaged in drug trafficking. Officers claimed the reason for stopping the vehicle was to issue a warning about traffic violations as a pretextual stop. The defense argued that vice officers don't make routine stops and it was as a pretense to conduct an investigation where they lacked suspicion. The Court found that motivation behind a traffic stop is not relevant to Fourth 
Amendment inquiry which allowed police to conduct investigatory stops based on any factor including race (Gizzi \& Curtis 2016).

In Whren v United States, the Supreme Court unanimously found that a pretextual motive cannot invalidate a stop where probable cause exists. The Supreme Court rejected the "would" test in favor of the "could" test, which asks whether the officer could have validly made the stop despite a pretextual motive. Had the "would" test been applied the burden of proof to justify the stop would shift to "would" the officers have validly made the stop despite a pretextual motive (Gamrath 1997). The Court ruled that prior precedent cannot invalidate police conduct when it is justified by probably cause. Subjective intentions and actual motivations play no role in a probable cause analysis under the Fourth Amendment per the Supreme Court, a finding that was detrimental to the rights of citizens regarding the Fourth Amendment. Though the Fourth Amendment says reasonable doubt or probable cause must exist for people to be stopped, the Courts have allowed police to make stops on pretexts (Harris 1999). While this does provide opportunity to generate revenue for the justice system, an argument exists that pretextual stops infringe upon the rights of the public.

The Whren decision has had a significant impact on the allowance of pretextual investigative stops causing it to be viewed as a victory for law enforcement. This decision gave police the authority to search any vehicle that has violated any provision of the vehicle code. Close to, if not every driver, violates some provision of the code due to the existence of many different potential infractions (Harris 1999).

Post Whren, officers can circumvent the reasonable suspicion requirement for a Terry stop by following a motorist until the driver inevitably breaks any traffic codes, or can fabricate justification for the most trivial of traffic violations. The officer is then able to mask the 
prefabricated "hunch" which resulted in the stop in the "objective probable cause" of the traffic stop. As a result, law enforcement does not have to justify the stop in the same manner a Terry stop requires. The existence of the traffic violation completely justifies the stop, even though the officer's underlying intent is to conduct a criminal investigation when lacking the articulable facts and inferences from facts required for reasonable suspicion. The pretextual nature furnishes the officer with an avenue to conceal their true motives and intentions behind the traffic-stop. Having the ability to conceal their intentions allows officers to easily rely on stereotypes such as race to select who to stop (Hecker 1997). Judge Pendleton (2014) further added that reasonable suspicion must meet the following criteria; "at least a minimal level of objective justification," and the stop must not be based upon "mere whim, caprice, or idle curiosity." The threshold question in every motor vehicle stop is whether, under the circumstances, the officer acted reasonably.

The Whren decision became the source of widespread academic criticism (see, e.g., Lawton 2008). This criticism stems from the fact that the decision in effect authorizes racial profiling in run-of-the-mill traffic stops, a common modern law-enforcement technique. By many accounts, racial profiling currently is routine among state and local police in jurisdictions across the United States. It has become an integral tool employed in the much-maligned, yet aggressively enforced war on drugs (Johnson 2016). It, therefore, contributes to the prevalence of racial profiling in the modern United States. Whren v. United States ruled that stops are legitimate if they are caused by any objective violation of statute. The Court directly addressed the constitutionality of the practice of racial profiling in Whren. The defendants were two motorists who were charged with drug offenses based on evidence discovered after they were pulled over for pausing at a stop sign for an unusually long time, turning without signaling, and 
taking off at an unreasonable speed. The Court held that the Fourth Amendment is not violated when a minor traffic infraction is a pretext rather than the actual motivation for a stop by law enforcement officers (Feder 2012). Though race may have been a major indicator and racial profiling may have been used to conduct the stop, the Court largely ignored the racial profiling aspect of the case in determining that it was not the subjective intentions of the officer that determined whether the stop was legal. Instead it was determined to be a legal stop due to the objective traffic violation meeting the criteria to necessitate a traffic stop (Gizzi \& Curtis 2016).

Following Whren, the Court's holding in Atwater v. Lago Vista (2001) extended Belton to include minor traffic offenses. In Atwater, the defendant was arrested for driving without a safety belt although the violation of driving without a seatbelt is a misdemeanor offense carrying the sentence of a fine. In disputing the custodial arrest, the defendant sued the city of Lago Vista. The Court found that the arrest satisfied constitutional requirements due to there being no dispute that the defendant had committed a crime in the officer's presence, and because she admitted that she and her children were not wearing seat belts. In the majority opinion, the Court stated, "when a police officer has probable cause to believe a traffic violation has occurred, the officer may stop the car, arrest the driver, search the driver, search the entire passenger compartment, including any purse or package inside, and impound the car and inventory all its contents (Souter 2001)." Atwater permitted the arrest of motorists for the most minor of traffic offenses, even non-jailable offenses.

The trend of continuing to expand police power regarding traffic searches continued in Thornton v. United States (2004) when the Belton rule was again extended to allow the search of a vehicle when the arrestee was no longer in the vehicle but was in close proximity to the vehicle and a recent occupant of the vehicle. In Virginia v. Moore (2008), Moore was arrested for 
driving on a suspended license which isn't a custodial offense in Virginia. The Court found in favor of the state. In the majority opinion, Justice Scalia stated if objective probable cause exists that a traffic violation had occurred, the motorist could be arrested regardless of the offense.

The Belton rule, and its open-ended ability to conduct passenger compartment searches was significantly curtailed by the 2009 decision Arizona v. Gant. In Gant, the Court revisited the Fourth Amendment challenge to vehicular search incident to arrest after the driver has been arrested, handcuffed, and secured in a squad car on the grounds that neither of the rationales in Chimel; police safety or preserving evidence; were enough to justify arrest in this case. The Court held once an arrestee is secured and prohibited access to the vehicle that police cannot conduct a search incident to arrest unless it is found reasonable to believe evidence relating to the crime of arrest may be inside the vehicle (Armacost 2009).

Gant, in effect, ended the Belton rule with the exception of cases where it is found reasonable to believe further evidence of the crime of arrest would present if a search of the vehicle were to be conducted. Arrests for driving without proof of insurance would no longer permit a Belton search. While Gant narrowed the tools available to police conducting searches, in many ways it forced them to rely on other ways (such as seeking consent, impounding vehicles to conduct an inventory search or using a $\mathrm{K} 9$ narcotics sniff) to provide probable cause for a vehicular search (Gizzi \& Curtis 2016). The case did not place any limitations on the types of issues that individuals could be arrested for, nor did it address the question of pretextual stops. Police are free to stop any motorist or vehicle on probable cause of a traffic violation, they can arrest for any offense, but can only search when it is reasonable that further evidence of the crime of arrest will be found. 
Additionally, not all states have applied Whren to their policy. New Mexico v. Ochoa (2009) found that the combined factors of the academic criticism of Whren, precedent, examining other states' law, and New Mexico's concept of liberty that as a state they should be precluded from Whren's findings (Sieverts 2014). Epp et al (2014) state that the courts need to take steps to stop investigatory stops instead of aiding in legitimizing them. The recent increase in prodefendant findings may lead to stricter regulations or stoppage of the practice of investigatory stops.

In Herring v. United States (2009) when an expired warrant was not removed the subject was arrested and further contraband was found. Chief Justice Roberts found that the sole purpose for the exclusionary rule was to deter illegal police misconduct. The seizure and arrest were allowed due to the stop being the result of a clerical error and not illegal police misconduct. Arizona v. Johnson (2009) allowed pat downs to be permissible if reasonable suspicion exists that the passenger may be armed and dangerous.

Navarrete v. California (2014) gave law enforcement added discretionary powers by allowing the use of anonymous narcotics tips to be bases for traffic stops (Hvidston 2014). In Navarrete, the Court allowed evidence from a stop that was conducted based on an anonymous tip of impaired driving due to a motorist trying to run another motorist off the road. After following the motorist for an extended period, the officer conducted a traffic stop which upon further investigation yielded 30 pounds of marijuana. The Court found the stop to be admissible based on the totality of circumstances, including the 911 call and specific information provided including the license plate number, location of the vehicle, and a plausible description of wrongdoing to justify the stop (Gizzi \& Curtis 2016). 
The previously mentioned cases had effectively put Fourth Amendment rights and citizen's privacy in question. Katz v. United States (1967) strayed from the trend of empowering law enforcement through a prodefendant decision allowing the defendant and citizens a reasonable expectation of privacy. The issue in Katz was that he had been making gambling calls from a phone booth. Law enforcement installed a monitoring device on top of the phone booth and used the evidence obtained to arrest the defendant. The Supreme Court held that the search of the phone conversation was not admissible due to Katz having what he and society would deem a reasonable expectation of privacy.

Investigatory Stops and the War on Drugs

The widespread use of profiling in investigative patrols in Operation Pipeline were a key conditional piece of using investigatory stops as a tool to fight the war on drugs. Investigatory stops have developed into one of the most frequently performed drug interdiction techniques (Epp et al 2014). The government, through policy making and Supreme Court decisions, has encouraged officers to utilize the traffic code as part of the war on drugs (Alschuler 2002). The war on drugs failed to produce the desired effects on drug usage, drug trafficking, and reduction of crime rate. While refusing to admit the war on drugs was a failure, the government has used policy and Court findings to increase police discretion and ability to commit search and seizures to achieve the desired results. This argument has been reinforced through the continually increasing invasiveness allowed in policing and investigatory stops which most heavily impacts minorities. Previous Court findings have allowed for the use of profiling (Sokolow), other cases simply ignore the use of profiling (Whren), the arrest of a motorist on any traffic violation (Atwater), search of the vehicle incident to that arrest (Belton), allow an officer to search a vehicle if an arrested party is in close proximity to the vehicle or recently occupied the vehicle 
(Thornton), and to order passengers out of stopped vehicles (Wilson). These findings have provided constitutional protection to police officers while taking away privacy rights from motorists. This constitutional backing to allow easier search and seizure of vehicles for nearly any reason dramatically increases drug seizures and arrests, making a valuable tool for the war on drugs.

The use of profiling for investigative stops is also used in the war on drugs. When Blacks are pulled over on pretextual investigatory stops at a far higher rate than Whites for similar driving patterns, it is logical that they will constitute a higher percentage of offenders. Profiling is a well-known component of a criminal justice system that critics contend is racially biased (Johnson 2016). Investigatory stops are the main source of racial disparity in police stops (Epp 2014). Police attempt to justify the disparity in stopping Blacks by arguing that Blacks are pulled over more frequently because they commit more traffic infraction than Whites. In addition, the false claim of Blacks selling and using drugs more frequently than Whites is attributed to the disparity in charges and stops involving blacks when in facts the sales and use of drugs amongst race is similar. Another attempted justification is that due to Blacks' class and lower socioeconomic status they are more likely to be suspect and pulled over (Epp et al 2014). This disparity in race of incarceration rates in drug cases and in investigatory stops is not coincidental. Due to the use of profiling in these stops and the stops being a main contributor to drug interdiction and incarceration rates, these factors can be related to the racial disparity seen in the war on drugs.

Though they are viewed by much of society and academia as an infringement on rights and violation of the Fourth Amendment, police and policy makers to justify pretextual stops for numerous reasons. A major incentive for pretextual investigatory stops is the ongoing war on 
drugs (Banks 2016, Harris 1999, HDI 2016, Johnson 2016). Incentives include, first and foremost, the prosecution of the drug war, high arrests numbers, contraband seizures, and large scale drug busts. All of these factors make investigatory stops look favorable to the public (Banks 2016). PoliceMag states, “you can’t singlehandedly win the war on drugs, but with keen eyes and attention to detail on traffic stops you can make an impact" (Murgado 2012). Officers may make an impact on their department or area, but they are far less likely to have an impact on the war on drugs as a whole.

The Use of Profiling in Investigatory Stops

The use of profiling pre-dated Operation Pipeline. Its use began to increase in the late 1960s due to the allowance of Terry Stops and again in the late 1970s under the term "aggressive patrol.” These aggressive patrols utilized "The drug courier profile." The use of profiling was then adapted to bus stations and finally automobiles (Cole 2000). The drug courier profile was developed in the early 1970s by a single agent of the Drug Enforcement Agency (DEA) for use in investigating commercial air passengers suspected of carrying illegal narcotics. Special Agent Paul Markonni is credited with developing the profile while assigned to the DEA's Detroit office (Cespedes-Yaffar et al 2010).

Although Agent Markonni was the first to apply the use of a profile in addressing the nation's drug problem, the concept was first utilized by law enforcement in the United States in 1968 by the Federal Aviation Administration (FAA) to remedy an increase in skyjacking issues. In 1968, a specialized task force was appointed by the FAA to apply investigation methods for combatting hijacking. Experts were enlisted to conduct field tests and studies to design a multifactor profiling system that was designed to prevent further hijackings (Cespedes-Yaffar 2010). An integral component of the system was the development of a "skyjacker profile." In 
instances that a passenger boarding an aircraft was observed to fit this profile, airline employees and FAA agents would target that passenger. The implementation of the program was highly effective at reducing the number of airplane hijackings throughout the United States (CespedesYaffar et al 2010). Due to the high level of effectiveness of profiling, by 1979 the skyjacker profile was in use in over twenty airports. By 1985 , the drug courier profile had extended to airports from Florida to Washington and New England to southern California.

Currently, police and agents throughout the country utilize the drug courier profile, adapted from the skyjacker profile by Markonni, in a relatively uniform manner in airports, bus terminals, and pretextual investigatory stops on roadways (Cespedes-Yaffar et al 2010). In U.S. v. Hernandez-Cartas, (1991) Judge Hill states;

"drug courier profiles are inherently prejudicial because of the potential they have for including innocent citizens as profiled drug couriers. Generally, the admission of this evidence is nothing more than the introduction of the investigative techniques of law enforcement officers. Every defendant has a right to be tried based on the evidence against him or her, not on the techniques utilized by law enforcement officers in investigating criminal activity. Drug courier profile evidence is nothing more than the opinion of those officers investigating. Although this information is valuable in helping drug agents to identify potential drug couriers, we denounce the use of this type of evidence as substantive evidence of a defendant's innocence."

The jurisprudence of Judge Hill's statement applies to the use of racial profiling in investigative stops as well as their use in drug courier profiles. Characteristics that often lead an agent to stopping an individual that fit a drug courier profile often ended in the investigation of innocent people. The courier profile was largely subjective and depended on "hunch" on the part of the agent (Bernstein 1990). A lack of objective standards made it impossible to apply the standard of reasonable suspicion determined in Terry (1968).

Though the Supreme Court tends to ignore the presence of racial profiling, in $U S v$ Sokolow (1989), the Court upheld the use profiling in general in the context of "drug courier 
profiling." In Sokolow, the defendant was stopped by the DEA upon arrival at the Honolulu Airport. Justification for this stop was the facts that he paid for the tickets with rolls of $\$ 20$ bills, the phone number listed did not match the identity provided, the window of the total round trip time for the trip was 48 hours though it included 20 hours of flight time, he appeared nervous, and checked no luggage. The Court further held that the fact agents used the "drug courier profile" does not alter this analysis due to the factors having evidentiary significance regardless of whether they were contained in the profile. While the Court has yet to rule on, or even acknowledge the use of profiling in investigatory stops, Sokolow set a precedent in allowing the use of profiling.

Police reform in the 1970s and 1980s brought about a major change that caused police to stop being as lax. A major factor of this shift was the appointment of conservative Supreme Court Justices who favored the crime control jurisprudence (Gizzi 2016). Through the Court's findings providing more power for police and less rights to privacy for citizens, law enforcement increased the use of investigative stops. The justification of investigative stops at this juncture was that a higher level of contacts with motorists reduced crime. With the development of broken windows policing in the early 80s, police were encouraged to arrest citizens for any offense regardless of the levels of seriousness (Fagan 2000).

Police departments across the United States routinely engage in racial profiling in traffic stops. African Americans, Latina/os, and other minority groups are profiled by law enforcement. As these descriptions of law enforcement abuse suggest, the racially disparate consequences of law enforcement are widely considered a serious national criminal justice problem (Johnson 2016). The underlying conditions that divide race and socioeconomic status need to be addressed to effectively decrease the amount of racial disparity in stops or system wide. (Epp et al 2014). 
This general acceptance of policies that yield results causing a racial disparity causes law enforcement to believe these are necessary and routine practices that are highly effective. (Gizzi 2016). Thus, the usage of racial profiling becomes accepted and institutionalized practice amongst law enforcement.

The Whren decision ignored race and stated that if the officer had objective probable cause of a traffic violation, their underlying motivation for the stop did not matter. The issue lies in that it is impossible to prove and no law enforcement officer is going to openly, readily admit that they pulled a motorist over due to their race (Hecker 1997). Though investigative stops continue to be a nationwide issue, some states have made efforts to combat traffic stops initiated on unconstitutional grounds of racial profiling, yet state courts are finding it hard to prove racial profiling was applied in the absence of police admission of using a pretext due to the presence of a traffic violation, whether one is fabricated or actually present (Lawton 2016).

Racial profiling and investigatory stops were institutionalized by a motivation to conduct pretextual investigative stops through training, propaganda, and educational materials (See e.g. Police Chief 1996). Through numerous findings, the United States Supreme Court has told us that the test for a Fourth Amendment violation is purely objective; the subjective state of mind of the officer is completely irrelevant while conducting the stop. (O'Neill 2009). In Whren v. United States, the Court indirectly authorized traffic stops based on the race of persons in the vehicle. The Supreme Court was provided the chance to remedy the racial issue of pretextual investigatory stops through the "reasonableness" requirement of the Fourth Amendment. Narcotics suspects were stopped for moving violations, the drugs seized in plain view were admissible because the court ruled that the officers' subjective reason for making the stop, even if admittedly as a pretext for criminal investigation, did not invalidate the stop (Rutledge 2005). 
This case had the potential to control unchecked police discretion and the use of race as a controlling factor in traffic stops. Including, though not mentioning racial profiling, the Court chose to side with law enforcement and allow officers to retain all previous discretions to continue the war on drugs (Hecker 1997).

Police argue that they do not overuse race, but use it in combination with other factors that make it more likely that a subject may be involved in drug trade or trafficking. Even the partial usage of race as a determinant to perform pretextual investigatory stops would lead to a disparity amongst races (Hecker 1997). This disparity is reason for concern and questions the legitimacy of the usage of investigatory stops.

The authors of law enforcement manuals have learned to apply techniques in investigatory stops that attempt to circumnavigate the legal definition of profiling and conceal the use of racial profiling in the selection of motorists. Remsberg (1995) suggests that officers keep a log book of all stops for severely minor offenses such as following too closely, failure to dim lights, impeding traffic, or letting hoses rub metal on semis so when an investigatory stop is successful in producing an arrest or seizure of contraband it shows they weren't engaging in profiling. This tactic disregards the fact that they are pulling over numerous vehicles for extremely minor offenses. In a continued attempt to conceal the use of profiling, this strategy also suggests that officers do not forget to issue a warning or minor traffic citation as otherwise it would show that you were never concerned about the minor infraction. Not doing so will show that the officer was primarily concerned with the major infractions that developed from the stop and not the minor infraction for which the motorist was stopped (Remsberg 1995).

Profiling in pretextual investigatory stops still exists although it is now far less overt. Police chiefs admitted at a conference in 1999 that minorities are angered for both being stopped 
and being stopped for reasons other than what the officer tells them. Policing management and policy makers should prioritize race relations above the potential arrests of addicts and lower level dealers, the lingering anger of minorities for being stopped unjustly in investigatory stops could have substantial and possibly permanent implications (Epp et al 2014).

Epp et al (2014) identify several issues involving race and the use of pretextual investigatory stops. He states that in traffic safety stops it is a traffic violation that causes the motorist to be stopped, however, in investigatory stops it is the level of suspiciousness in which race may be a determining factor. While race rarely plays a role in the enforcement of traffic laws it has substantial relevancy in the enforcement of drug laws. Two dangers that occur in this practice is the prioritization of race by law enforcement in the apprehension of drug traffickers predominantly targets black motorists for police attention, and that a potential of abuse of discretion exists when race is a factor in deciding the targets of investigatory criminal stops (Hecker 1997).

Other actors in our justice system, such as judges don't see the full scope of pretextual investigatory stops due to only seeing those who are cited or arrested. Police also do not see this as harmful as they only see the motorist for the duration of the stop and the motorist is likely to remain stoic throughout the encounter. Those who study these encounters and their effects, social scientists, observe that pretextual investigatory stops may cause long lasting harm due to minorities feeling demeaned and abused. The feeling of being demeaned, abused, or treated in a condescending manner, may cause a fear or distrust of police that will make minorities less likely to rely on police assistance or to cooperate with investigations (Epp et al 2014).

Epp found minorities viewed police racially discriminating, untrustworthy, rude, unfair, uncaring, and lack confidence in them. The main causation of this is the manner of the stop that 
they experience. Minorities are far more likely to be victims of investigatory stops than Whites. Epp showed that while Whites make up 58\% of traffic safety stops in comparison to $32 \%$ of Blacks, Blacks make up 52\% of low level infraction stops in comparison to $34 \%$ for Whites. Epp et al. (2014) also found that Blacks are 2.7 times more likely to endure investigatory stops than Whites. Government reports state that 80 percent of the United States cocaine users are White and the "typical" user is a middle class, White, and a suburbanite. However, policing tactics, including investigative stops concentrate their efforts on the inner-city drug trade that is mostly comprised of minorities. This tactic aides in creating a racial disparity in drug charges and adds to the incorrect assumption that most drug dealers are Black or Latino (Harris 1999). The profile, described by one court as "an informally compiled abstract of characteristics thought typical of persons carrying illicit drugs," had been used in the war on drugs for some time.

By the year 2000, it was estimated that over a third of criminal arrests resulted from stops for minor traffic violations (IACP 2000). In May 2001 alone, 1,471 fugitives and 254 stolen vehicles were recovered during stops for seatbelt violations (Police Chief 2002). Seizure records from the Department of Justice indicate 61,998 seizures were made without warrants or indictments from 9/11/2001 to 2014 (Sallah et al. 2014).

Anatomy of an Investigative Stop

Law enforcement literature on pretextual investigative stops is often concealed. Numerous sources provide only superficial information relating to training courses or programs that focus pretextual investigatory stops under alternative nomenclatures such as "aggressive patrol" and "proactive patrol." However, Remsberg's training manual for investigatory stops (1995) goes into great detail, providing a step by step pyramid designed description of the goals and procedures of investigative stops. The base level of the pyramid in this model is to develop 
suspicion. Suspicion is developed through observation. The second level of Remsberg's pyramid is to develop justification for the stop. This is done by observing a traffic violation, vehicle equipment infraction, or by running plates to develop a reason to pull the motorist over. Though most manuals and policing literature have shown intent to search exists before contact with motorists, the third level of the pyramid model is to decide whether to search the vehicle. Officers are trained to use a strategic manner of discourse to convince the motorist to give "consent" for a vehicle search. The following three steps are: search the vehicle, discover contraband, and arrest the subject. The apex of the pyramid, titled bonus benefits, involves monetary seizures, seizure of the vehicle, or additional criminal charges. Remsberg's pyramid model illustrates how a subjective suspicion, generally based only on appearance, develops into a criminal investigation of a motorist.

Rutledge (2005) offers a different approach to pretextual investigative stops by utilizing the loophole arresting subjects on minor traffic violations. The first step in this tactic is to observe moving or equipment violations, preform the traffic stop, safely order occupants out of the vehicle, request the consent to search, arrest the driver for the traffic violation, search passenger compartment incident to arrest, impound and inventory through standard procedure, and do not abuse your discretion as it is an inappropriate application. The purpose of arresting the driver in these incidents is that it allows the officer legal access to search the passengers, their belongings, and the entire vehicle, incident to the arrest of the driver (Rutledge 2005). Studies reveal that the efforts of special drug enforcement units cause vastly disparate targeting of minority motorists. When police make 'Terry Stops' based on a reasonable and articulable suspicion of drug activity, they may be forced to defend their use of race as a probative factor in stop decisions (Hecker 1997). 


\section{Procedural Justice and Investigatory Stops}

An argument exists whether procedural justice is a potential remedy to the racial divide and mistrust resulting from pretextual stops or another way to conceal racially biased motives. Banks (2016) argues that to mend the relationship between Black citizens and police it is necessary to reprioritize law enforcement strategies in low income, high crime areas that have the most need. If attempted, this would necessitate an improved understanding of police efficacy and a different, more service oriented, relationship between police and the communities they serve. Many minorities fall victim to the encroachment on their rights due to the psychology of procedural justice.

Using a polite approach officers hide their true intentions making it more likely that motorists will be cooperative with the investigative stop and feel as though they were treated fairly, regardless of the outcome of the stop (Epp et al. 2014). Through repetition, even when an officer is polite, those who are subjected to these unjust, racist practices, will eventually see the unfairness in them. Moreover, by using trickery and deceit to elicit the cooperation of a driver or person suspected of no crime shifts an officer's role from protector and public servant in a position of trust to antagonist and interrogator — even if he is doing so politely. Black people who experience these stops, particularly those who experience it repeatedly, recognize the difference and often resent it (Banks 2016).

It is unfortunately a reality that law enforcement can pull anyone over for any reason at any given time. Many of the intrusive investigatory stops have legal precedence, thus leaving those who are victimized without legal recourse (Banks 2016). Minorities have developed a fear of officers that when they are stopped they believe not giving consent to an officer may result in 
criminal charges or worse. In situations such as these, consent is given unwilling out of fear of the alternative.

It goes without questioning that pretextual stops involve more innocent people, often minorities, than guilty people. A potential to alienate the public's relationship with police has underlying consequences that may be detrimental to society and police (Levit 1996). As Judge Allen Pendleton (2012) states; the legal threshold for investigatory stops is set "very low." Though any potential violation may justify a traffic stop, an actual violation need not occur.

\section{Civil Asset Forfeiture}

From a law enforcement standpoint, civil asset forfeiture is a major motivator for making pretextual investigatory stops (Epp et al, 2014; Johnson 2016; Remsberg 1995). Civil asset forfeiture provides an incentive for high numbers of police contacts and investigatory stops as it is a major source of funding (Remsberg 1995). Using asset forfeiture, investigatory stops reward officers and departments by providing funding through the sale of seized property and funds. This has caused the use of investigatory stops to continue to be a nationwide phenomenon that is even used in some foreign jurisdictions. Pretextual investigatory stops yield a value beyond what they are intended, thus they are deemed not just effective but right and proper. Though civil asset forfeiture was originally intended for use on large scale, highly lucrative drug operations instead of low level dealers on the side of a highway as applied here, little reason exists for law enforcement to cease investigatory stops as their departments and careers continue to benefit from civil asset forfeiture (Epp et al 2014). If a dog sniff hits on narcotics and none are found, monetary civil asset forfeiture can still occur without law enforcement having to admit wrongdoing leaving little reason to cease investigatory stops (Sallah et al. 2014). Those who make major busts are also individually praised and rewarded. Law enforcement tend to make 
more stops, giving them higher probability to make large busts. Officers are aware of different areas being more likely to have motorists with contraband and will target these areas.

Due to recent decisions legislation provides more of an incentive to continue investigatory stops than to decrease or stop their use (Johnson 2016). Police are not held accountable for conducting stops based on insufficient grounds, yet there are still instances where they benefit from seizures and forfeitures even if the case is dismissed. Armed with the knowledge that actual suspicion isn't necessary to conduct a stop and have it hold up in court proceedings, officers, policy makers, and private training firms see investigative stops as avenue to generate revenue.

\section{Law Enforcement Justification of Pretextual Investigatory Stops}

The National Traffic Highway Safety Association attempted to show that traffic and criminal enforcement are related through conducting a course called "Conducting Complete Traffic Stops: A Crash and Crime Reduction Effort.” This course taught officers to legally conduct interdiction techniques and exercises during routine traffic stops (Runge 2002). Georges (2000) made another effort to attempt to legitimize the usage aggressive traffic patrol techniques, by stating that the main goal of these techniques was to increase traffic safety and an added benefit was that it decreased crime. In the attempted justification of these techniques, he states "one of the best crime prevention tools is a police car making a traffic stop."

Officers such as Lt. Hawkes (2012) attempt to justify investigatory stops by attributing different types of crime to traffic stops. In Police One magazine he claims that homeland security would be jeopardized by ceasing or stricter regulations on investigatory stops. Hawkes further claims that human trafficking, sex trade, and immigrant trafficking would all become larger scale criminal enterprises if investigatory stops were not as widely used. He also attempts to justify 
searching laptops, identification, and all financial instruments when conducting a search to deter interstate identity thieves. These attempts to justify investigatory stops are reaching at best and borderline paranoia at worst. The idea of using invasive stop techniques on high numbers of motorist to apprehend a small percentage is unethical and a waste of resources that could be better spent elsewhere. 


\section{CHAPTER III: RESEARCH QUESTION AND DESIGN}

Examining the Research Question

This thesis seeks to examine the argument made by Epp et al. (2014). Epp argued that at the very same time police were condemning racial profiling, they were simultaneously championing the use of traffic enforcement as good police work. They condemned racial profiling in investigatory stops, but then argued that investigative traffic stops were the key to effective crime control. While condemning the use of racially-motivated factors, they then encouraged use of the same factors, without referring to race. This research will address the question of whether Epp's argument is correct, and seek to more thoroughly explain how the racially biased practice of pretextual investigatory stops evolved from a tactic specifically intended for the war on drugs to a routine day to day practice using techniques that are supported in policing literature and police culture under the false premise of "selling" an invasion of motorist privacy as good police work?

Investigatory stops are a topic that has disparate views depending on the viewer. Those in law enforcement tend to have favorable views on pretextual investigatory stops for a variety of reasons. Due to the institutionalized beliefs and benefits they may receive through conducting numerous investigatory stops police may view them as a necessary and effective tool in the war on drugs and to deter crime. Most of those in academics with an in-depth knowledge of investigatory stops view them as a violation of the Fourth Amendment, a tactic is racially biased, creates a distrust/fear of police, a strained relationship between police and the community, and an invasion of motorists' privacy.

Epp presents the argument that police have applied the use of racially motivated investigatory stop methods, including racial profiling, designed for use in the war on drugs into a 
routinely used day to day method of policing with the primary means of drug interdiction on highways, police and law enforcement have essentially given a new name to what had been considered racial profiling while claiming traffic interdiction was the primary focus although they tactics are the same. To frame this argument, Epp mainly relied heavily on exploring Remsberg.

\section{Defining Narrative Review}

This research will be conducted through a qualitative narrative review. A narrative review is a far more focused literature review combining the findings from numerous sources addressing the above research question. According to Campbell Collaboration (2001) and Kirkevold (1997), a narrative review summarizes various primary studies and draws holistic conclusions that are best suited for comprehensive studies. Literature reviews are generally divided into three types: systematic review, best evidence synthesis, and narrative review. As previously stated, this thesis is employing a narrative review. Narrative reviews are publications describing and discussing a specific topic or theme from contextual or theoretical perspective. In narrative reviews the types of databases and methodological approaches used to conduct the review are not typically listed.

Narrative reviews consist of critical analysis of the literature published in books and electronic or paper-based journal articles (Bernardo 2004). With that being said, results of narrative reviews are qualitative. These reviews play an important role in continuing education by providing readers with up-to-date- knowledge, identifying previously conducted works, allowing consolidation, identifying gaps or omissions, and/or furthering previous research as this thesis will (Grant \& Booth 2009). Grant and Booth also state that these articles can consider a 
wide range of material at varying levels of entirety and scopes of research based on analyzing different sources of literature.

Analyses will clarify if and how investigatory stops have been transformed into standard procedure in policing from their roots in Operation Pipeline, if racial profiling is actively used in investigatory stops, and if profiling is used, are police aware of its usage and do they attempt to conceal their knowledge of racial profiling day to day policing?

The use of training manuals, policing magazines and training program literature will be examined to show the similarities or changes in the prevalence of investigatory stops, the use of profiling in investigatory stops, the attempted concealment of terminology denoting racial profiling, and differences in terminology due to the audience the article was intended (See Appendix A for complete list of sources analyzed). Due to the intended audience of these magazines and training programs being mainly comprised of police officers and law enforcement, it is possible that the concealment of profiling, attempting to make questionable stops legal, and other questionable methods are included in these readings.

Supreme Court decisions will be used in a chronological manner to determine the corresponding differences, if any, in policing literature on investigatory stops and certain Court decisions. Legal standing on the use of pretextual investigatory stops has changed over the course of time in which the examined sources have been written. This study will further explore this literature and determine if changes in terminology or policing policy in general occurs. Through this extensive narrative review of the sources above, this research will determine if pretextual stops have revolved from a war on drugs tactic to routine police work and if unconstitutional techniques are supported in policing literature and police culture attempting to convince the public that the invasion of motorist privacy is good police work. 
This work will not be without limitations. Due to the scope of time and material of the literature being reviewed it will not be possible to look at all available literature. The objective is to select literature that is representative of the entire body of research regarding investigatory stops. Narrative reviews are also subject to selection bias as the author may unintentionally select only works that will support their hypothesis. Additionally, due to the lack of complete and detailed research methodology section, duplicating the research and data may not be possible. 


\section{CHAPTER IV: RESULTS}

Epp et al (2014) present the argument that police and law enforcement use racially motivated stop methods, including racial profiling, that were originally intended for use in the war on drugs and developed them into a routine, nationwide policing tactic that has become the primary means of highway drug and criminal interdiction. While the names of the practices and profiles have changed, the tactics employed by law enforcement in investigatory stops retain the same focus. Epp relied heavily on Remsberg's (1995) Tactics for Criminal Patrol: Vehicle Stops, Drug Discovery, and Officer Survival. This narrative will examine Remsberg's manual, other interdiction manuals, interdiction course literature, police magazines, journal articles, books, and government reports to determine if Epp's argument withstands further scrutiny.

Operation Pipeline, The War on Drugs, and the Origins

$$
\text { of Investigatory Stops }
$$

Before Operation Pipeline and the proliferation of pretextual investigatory stops, policy makers, particularly those supporting crime control jurisprudence, called for a shift in patrolling tactics from random patrol to a more aggressive patrol (Wilson 1978). The DEA began employing the origins of the modern investigatory stop through the implementation of Operation Pipeline with the intention of combatting drug smuggling near the Mexican-American border. Though many other factors existed, race and ethnicity were primarily referred to in developing the original drug smuggler profiles in Operation Pipeline training. Though Sheriff Vogel, whose techniques aided in pioneering investigatory stop tactics, insisted upper level drug dealers consisted of white males, the DEA still applied training methods focused on ethnicity, race, and subgroups in society. Some early DEA Operation Pipeline manuals illustrate how stop methods focused on minorities in traffic policing. One videotape (DEA 1986) intended for training the 
New Mexico state police used several indicators to demonstrate example of probable drug traffickers, yet all examples used in the video portrayed the traffickers as Latinos. Another video of the early Operation Pipeline era, described by an attorney specializing in profiling cases (Buckman 2000), emphasized Jamaicans as the ethnicity running the drug in certain geographical areas. Examples of drug traffickers in this video consisted of a black man in casual clothing with dreadlocks and another black man in a business suit before instructing trainees not to be fooled, a drug dealer could look like anything or anyone.

Though early training literature and videos mentioned the use of profiling and focused on ethnicity, the DEA consistently has denied that race has, or ever has had any role in Operation Pipeline. While the DEA claims they have trained police not to consider race when deciding to pull over a motorist they do admit to the use of "indicators" (Harris 2002). Race is never directly mentioned, but traits and characteristics such as dreadlocks or two Latino males driving together are considered indicators. As the DEA simultaneously claimed not to use race as a justification for stopping motorists (1999), the agency and other federal law enforcement agencies provided information to other state and local drug interdiction agencies that emphasized targeting racial and ethnic characteristics of those involved in drug trafficking organizations. A 1999 DEA report stated "predominantly wholesale traffickers are Columbian, followed by Dominican, Chines, West African/Nigerian, Pakistani, Hispanic, and Indian. Mid-level dealers are Dominican, Columbian, Puerto Rican, African Americans, and Nigerians.”

Officers are to intercept contraband through the use of a "profile" of drivers and vehicles considered most likely to be a part of drug shipments. These characteristics evolved from subjective impressions and arrest experiences of DEA agents, especially of those assigned to work in airports. Although officers on patrol generally offer the pretext of a traffic violation for 
stopping a profiled driver or vehicle, many motorists (especially minorities) were pulled over primarily-sometimes solely- because they exhibited some or all of the profile earmarks (Gizzi 2016).

The DEA stated that race was just one of many "indicators." Indicators mentioned in a 1987 New Jersey State Police training memo included minority combinations of vehicle occupants in their descriptions of those likely to be involved in the drug trade. Deputy Director Debra Stone of the New Jersey Department of Law and Public Safety (Kocieniewski 1999) stated that racial profiling was deeply ingrained in New Jersey's policing culture. Racial profiling tactics were even taught to minority troopers. Regardless of the explicit meaning, troopers in their police vehicles have an implicit understanding of profiling tactics. Interdiction manuals and police leaders make no direct mention of profiling in recent literature other than to condemn its use. One must further examine policing literature, as well as stop data, and journal articles to determine if racial profiling is still implemented in investigatory stops.

Amongst law enforcement agencies nationwide the importance of training as many officers in interdiction as possible is viewed as necessary to win the war on drugs. Police administration and police scholars have stated that investigatory stops are among the most effective crime fighting tools (Epp et al 2014). Findings supporting the use of investigatory stops, information on how to tactically make investigatory stops, increased knowledge of conducting these stops due to their widespread implementation and training, accompanied by improvements and organization of stop tactics, have law enforcement convinced investigatory stops are an effective strategy for winning the war on drugs (Epp 2014). Eagleson reinforces this ideology by theorizing that interdiction is the best tactic available for the law enforcement community and that we are only finding $4 \%$ of all drugs due to spending all our funding on 
Homeland Security while the war on drugs takes a back seat. He further claims, "I can confidently say that the class I teach is one of a kind, and has been proven, many times over, to be effective in the war on drugs." The unfortunate reality of the war on drugs is that it turned routine patrol officers into drug law enforcement officers using investigatory stops as the primary tool (Provine 2007).

The message is continuous throughout policing literature and handbooks that the war on drugs is being lost and investigatory stops and interdiction efforts must be increased to win (Remsberg 1997, Haines 2011, \& Eagleson 2014). While traffic stops of an investigatory nature have existed to an extent before the implementation of Operation Pipeline, the inventors of the methods used as a war on drugs tactic in Operation Pipeline, along with police leaders, have turned investigatory stops into a systemic, formalized practice, developed training methods on how to legally conduct investigatory stops, and distributed knowledge amongst police departments through a campaign of proselytization (Epp et al 2014). Through a comparison of the Kansas City Operation Pipeline Training Manual, Remsberg's Tactic's for Patrol, and other more recent drug interdiction manuals, it is possible to illustrate the similarities that remain between early investigatory stop methods in comparison to recent and current handbooks, manuals, and policing magazines.

Lt. Kirk Simone: Operation Pipeline Passenger Vehicle Drug Interdiction Manual

The Kansas City State Highway Patrol Operation Pipeline manual (Simone 1997) directly follows Operation Pipeline guidelines as taught by the DEA. Similar to many later interdiction manuals, these early training manuals state that investigatory stops are based on high volumes of traffic stops, observations of indicators, a scripted roadside interview, and conducting searches by consent. This Kansas Highway Interdiction manual states that police on highway patrol must 
have an extensive working knowledge of traffic laws, conduct a high volume of traffic stops, and be able to look past the traffic violations that are causation for the stops to conduct in depth investigations following an interview (Simone 1997).

The early interviews (Simone 1997, Remsberg 1995) asked motorists for their point of origin, destination, reason for the trip, length of stay, type of work or purpose of visit, passenger names, how long they have known the passengers, if there were any drugs or weapons, any drug problems in the area, how should police address smugglers when they are encountered, what is the address the motorist plans on visiting, would there be any reason someone would call and describe your vehicle as that of a drug dealer, and instructions to hesitate after all questions before asking if the motorist is sure. These questions and hesitation were designed to force the motorist to become uncertain and nervous which would most likely lead to the emergence of indicators that could be used as reasonable suspicion or probable cause when used in combination. In the event multiple indicators were observed, officers are trained to escalate the traffic stop into an investigation that ultimately results in a vehicle search and potential arrest or seizure.

This training manual includes a section that instructs officers how to make their cases stand up to defense counsel, write their reports, how to prepare for court, and how to train your prosecutor into defending that the stop was legal (Simone 1997). Like this interdiction manual, Remsberg's (1995) manual provides a far more in depth illustration of investigatory stops, the motivation amongst police culture to continue their tactics, and how to properly conduct investigatory stops in a legal manner. 


\section{Remsberg: Tactics for Criminal Patrol}

Remsberg (1995) acknowledges that the tactics used in his manual are directly linked to Operation Pipeline by stating that state police and highway patrol have provided a leadership role in criminal patrol through the implementation of Operation Pipeline. He continues to argue that the techniques used were perfected through conducting hundreds of thousands of stops. Remsberg demonstrates the continued use of these tactics by stating the techniques that are learned here have been developed from Operation Pipeline and continue to "amaze and inspire" officers.

Throughout this 509-page book, Remsberg (1995) refers to investigatory patrol primarily as Criminal Patrol and also uses the terms such as make a difference patrol, aggressive patrol, criminal awareness patrol, criminal apprehension patrol, proactive patrol, and criminal interdiction patrol. Officers who participate in investigatory stops are thought of by other officers as "elite $5 \%$ ers" and the remaining police officers, whose primary focus is not on investigatory stops and drug interdiction are considered to be retired on duty (RODs). Further arguing that RODs are just glorified "mail carriers" who write tickets and deliver them to motorists. In addition to attributing a heightened status among police culture, Remsberg calls upon all officers to become criminal interdiction experts who participate in pretextual investigatory stops. The $5 \%$ does not just enforce traffic laws, the 5\%er is aggressive and proactive. The techniques on how to become a 5\%er are provided in an instruction like manner that also attempts to convince readers that investigatory stops are the most effective, efficient, and fun way to conduct patrol.

Under these guidelines, every vehicle has the potential to be a drug trafficker or violent criminal. Remsberg (1995) states that the core concept of Criminal Patrol is that vehicle stops are a golden opportunity for unique field investigations which, with the right volume of contacts, the 
right knowledge and creativity, and the right approach can make minor vehicle code infractions lead to major felony arrests. These calls are not limited in jurisdiction, Remsberg (1995) states that they can be applied anywhere and anytime. He further holds that these tactics, though rooted in the war on drugs are not limited to drug interdiction. The same investigative and control principles you learn and apply to drug interdiction can also help officers to succeed and survive in a broad range of other potentially dangerous situations such as high risk complaint calls, field interrogatories, and witness interviews. "Uniformed patrol officers constitute the most vital resource available against narcotics traffickers. They are the front-line, last-defense, street-level, street-fighting people who can make a difference" (p.15). The tactics discussed in this work provide instruction as well as work as a recruitment tool to further the proliferation of investigatory stops amongst law enforcement nationwide. Remsberg's manual has become the standard for teaching investigatory stops.

Remsberg provides a detailed description of the processes involved in investigatory stops and instructions on how to complete these tactics. Officers are instructed to sharply hone their skills of conversation, observation, and tactical thinking to successfully conduct investigatory stops. Remsberg (1995) teaches readers to goad motorists into being agreeable and then ask them, "do you mind if I take a look?" According to the manual, this is highly effective as $92 \%$ of all drug seizures come from consent searches. All visualization of the vehicle or even under the vehicle is not considered a search. Once the stop is made the officer is doing a sensory pat down to ascend the Criminal Patrol Pyramid, and officer is instructed to be constantly scanning the vehicle. If an officer sees an indicator, they are to build off it and attempt to find more indicators. One may not be sufficient for probable cause or suspicion, but a combination of multiple indicators may be. Officers using the tactics in this approach to patrol make it a priority attempt 
as frequently as possible to advance to the top of the Criminal Control Pyramid. The following explicit instructions related to the Pyramid are provided;

"With the foundation of legal contact (level 1) they use observations (level 2) and dialect (level 3) to learn more about the subject(s) they've stopped. If they become suspicious of wrongdoing, they mentally identify the reasons why, so they can later articulate their feelings as facts that courts will accept as reasonable. With reasonable suspicion (level 4), they ask for consent to search (level 5). Ideally, they discover incriminating evidence which gives them probable cause (level 6) for an arrest (level 7), converting the stop to a far different outcome than may have originally been anticipated. When circumstances are appropriate, they also lay the foundation for bonus benefits (level 8/apex) beyond the primary busts, including coconspirators and the seizure for forfeiture of crime related assets" (p.9).

Mental conditioning exercises such as crisis rehearsal, positive self-talk, and survival resources as discussed in Remsberg's other manuals; The Tactical Edge (1986) and Street Survival (1987). Law enforcement personnel are further instructed to never leave home without suspicion and take traffic stops seriously, which means to "go beyond the ticket" and look beyond simple driving violations. Conversational directions are provided to aid officers in knowing how to get the driver to cooperate with a request to search. Whether officers are initially suspicious of the vehicle or not you will use a traffic infraction or equipment violation as a legal basis for pulling the vehicle over. Once suspicion is aroused, officers are told to go as high up the Criminal Patrol Pyramid as possible (Remsberg 1995) by exploring the full arrest potential of each stop. Law enforcement are informed that any citizen can produce contraband and to go into every single 
stop expecting to find contraband. Patrol officers are told that all cars around them could be going to and from the commission of crimes.

Through recruitment, Remsberg (1995) attempts to justify the usage of all police officers as drug and criminal interdiction personnel. Justifications are offered such as these invasive techniques are used because police are overpowered and at firearms disadvantage. Therefore, techniques such as the investigatory stop must be used to even the odds. Another justification is that the desperation of traffickers to get away with the activities they are involved in will make them stop at nothing in an attempt to get away from you. Remsberg argues "all things considered, interdiction efforts (by patrol officers) offer the most effective and efficient return on manpower and resources of any narcotics enforcement program" (p.16). Potential perks of forfeiture from the usage of investigatory stops are retirement perks, new personnel, new weapons, new gun ranges, new surveillance and night vision gear, new cars, new CPU dispatch, new body armor, new mug shot comparison systems, new jails, new body-bug transmitters for undercover operations, new helicopters, new simulators, new exercise equipment, and many "wish list benefits." Remsberg attributes these perks to the use of regular patrol officers on interdiction patrol. The manual claims that when these investigatory stops are supported and encouraged at a departmental level officers far surpass the results of specialized units. You must be prepared to go into an armed conflict with each traffic stop. "The tactics that are revealed here constitute a way of working that can and should pervade all of your patrol experience, including foot patrol” (p.11).

Remsberg (1995) encourages officers to maximize the number of contacts they have per shift through the enforcement of traffic violations, know the vehicle seizure laws as they can be a great tool for drug interdiction, and to stop as many cars as possible with the goal of reaching 
reasonable suspicion. Officers are encouraged to stop as many vehicles as possible to get the numbers in their favor, as it is a numbers game in court, He further states the size of the drug problem has grown beyond what can be controlled by specialized units and widespread teaching of investigatory techniques will have a substantial deterrent effect (Remsberg 1995). Remsberg holds that the use of uniformed patrol officers as drug and criminal interdiction officers is legitimized by stating they are the most vital resource available against narcotics traffickers. If properly deployed patrol officers would be more effective with deterring other crime.

No matter the race, ethnic group, or nationality, officers are to expect contraband across all stop. The belief that drug interdiction should be relegated to interstates and highway patrol leaves out large areas and quantities where drugs are being transported (Remsberg 1995). Though anyone can have contraband, Remsberg (1995) mentions "the traditional profiling patterns continue to be frequently used, those who use it look for Hispanics, blacks, or any swarthy dark-haired outlander, sometimes accompanied by a white person. Although, using the profile as a reliable absolute has been discredited" (p.48). While they are no longer the standard, Remsberg states that they are closely correlated with a sizable portion of drug couriers.

The measures used in Remsberg's (1995) manual are thought of as borderline constitutional and hint at supporting profiling while simultaneously condemning it. Excerpts such as "today, officers rarely utter the "P word" except among themselves. For good reason, profiling has sparked controversy, lawsuits, and condemnation and is now officially prohibited amongst most agencies. Yet in practice, the old "traditional profile pattern" continues to be frequently used, (p.45)" proving that Remsberg as well as the police culture are aware that they are participating in racial profiling but it will not be detected if it is not mentioned. This is 
acknowledged again as the question; "How can I protect myself against accusations of profiling and arbitrary stops?" (p.69) is directly addressed.

Citing Whren; it is legal to be curious about a driver or vehicle first and then find a traffic infraction to justify pulling them over. Through this case the underlying motive for the stop is irrelevant if the traffic infraction occurred. The previous standard of proof was if a reasonable officer would have made the stop, but after the Whren decision it was amended to if a reasonable officer could have made the stop. This change allowed for far more leniency in the standard of proof involved for initiating an investigatory stop.

Remsberg takes full advantage of this by dedicating numerous pages to protecting the legality of questionable investigatory stops. The manual encourages officers to "cement your cases legally from start to finish so that they will hold up in court and will be shielded from civil liability" (p.10). The objectives of investigatory stops in this manual, or Criminal Patrol as they are referred to are to obtain voluntary consent to search vehicles and contents in the absence of a warrant, and expand investigations beyond roadside encounters for even more significant results. The entire process is covered in a context of legally preserving stops from the initial visual contact. Officers are told that to be successful at criminal patrol, their primary focus should be on what you can do and getting it to work for you, even if it means pushing to the edge of established limits. Remsberg preaches that officers can protect themselves by making a lot of stops.

Law enforcement personnel have been made aware that the safest way to secure a legal conviction is to determine clear cut probable cause. The best way to achieve probable cause is through the use of a traffic or equipment violation. A frequently used method is to intensely enforce traffic violations so that you can avoid accusations of profiling and arbitrary stops 
(Remsberg 1995). It is recommended that officers construct a "rolling resume" stating the age, race, and vehicle of each motorist and passenger they pull over. "This measure provides officers with the capability to justify the stops by showing they are extremely strict on traffic enforcement and builds credibility with the courts" (p.70). Officers are also reminded to be sure to issue a warning or ticket so there is confirmation that the justification for pulling them over is not to conduct an investigation.

Once a stop is completed, Remsberg offers guidelines for court testimony to avoid being accused of profiling which include; not using buzzwords like profile and not citing race or ethnicity as a justification for conducting the stop. Officers are trained to start thinking of their court case from the start of the potential case, meaning the entire procedure of the stop is conducted in a rationally planned manner intended to secure a major conviction. "When writing reports, officers are again encouraged not to use buzzwords or cite race in any way even if it did play a role in the decision to conduct the investigatory stop" (p.66).

With the foundation of a legal contact, officers use observation and dialogue to learn more about the subject(s) they have stopped. If they become suspicious of wrongdoing, they mentally identify reasons why, so they can later articulate their feelings as facts that the courts will accept as reasonable. With reasonable suspicion, they ask consent to search the suspect's vehicle. Ideally, the officer discovers incriminating evidence that gives them probable cause for an arrest, converting the stop to a far different outcome than may have originally been anticipated. When the circumstances are appropriate, law enforcement personnel may also lay foundation for bonus benefits beyond the primary busts, including the arrest of coconspirators and the seizure of crime-related assets (Remsberg 1995). 
Remsberg's Criminal Patrol has been a primary force in the proliferation of investigatory stops. This book is held as a standard by which to conduct the tactics of pretextual investigatory stops. Step by step instruction is provided to officers on how to conduct these steps. The literature then goes a step further and provides the officer with the tools necessary to making the practice of intentionally escalating traffic stops legally binding in court. Although Remsberg briefly discusses the approval of these methods by officers and police leaders, the proliferation and realization of employing the same methods under different terms is a routine nationwide phenomenon.

\section{Leadership Approval and the Discovery of Aggressive Patrol}

Policing and Operation Pipeline literature was more open regarding racial profiling in the early stages and initial proliferation of investigatory stops in the 1980s. They insist that the usage of profiling no longer exists in conducting investigatory stops. From this period until present, policing leaders have continuously stated that profiling no longer exists in current investigatory stops. However, numerous similarities exist between tactics that are currently employed in investigatory stops and those that were implemented during Operation Pipeline

The final stage of the construction of the legal application of investigatory stops was supplied via judicial decisions and policing leaders' responses to racial profiling and its opposition in the mid-1990s. Detaining people based on characteristics such as being male with a particular racial composition in a rental car on a major highway is controversial, but will be accepted in court as these findings have provided the court an avenue to determine this as admissible through a totality of circumstances via Whren (Brown 2001). In 1996, the Supreme Court considered the case of Whren v. United States. Whren claimed that he had been stopped for a traffic violation by a Washington DC vice cop because he was black and that he had been 
racially profiled. The Supreme Court held that if the officer held objective probable cause of a traffic violation, the officer's underlying motivation for the stop was irrelevant. In this finding the Court not only sanctioned pre-textual stops, but it also ignored the claim of racial profiling. Police had promised to end racial profiling and disparities in investigatory stops through the implementation of professional training and oversight (Gizzi 2016). The issue, was and remains that while police leaders continually condemn the use of racial profiling, they continue to endorse the usage of investigatory stops.

During the mid-1990s, policing leaders began to publicly endorse and praise the use of pretextual investigatory stops. In 1996, the International Association of Chiefs of Police (IACP) argued that police administrators had "rediscovered" the value of traffic enforcement. The IACP held that investigatory stops were an integral part of criminal interdiction, drug interdiction, and community policing. "An alert officer who looks beyond the traffic ticket and uses the motor vehicle code to sniff out possible criminal behavior may be our most effective tool for interdicting criminals" (IACP 1996). IACP president Bobby Moody (1998) stated "there can be no question as to the benefits of proactive traffic enforcement. The question is how does law enforcement enact a proactive program of traffic enforcement without antagonizing segments of the community and exposing our agencies to claims of bias. If handled improperly this situation can turn into the basis of charges of bias and result in costly litigations against police departments and agencies." Yet as a direct contradiction to this quote, in Police Chief (1998) magazine the IACP again endorsed the use of these stops as an effective strategy to protect the public from the widespread devastation caused by drug abuse, illegal trafficking, traffic related death, the continued freedom of fugitives, as well as to promote and maintain public order of a law-abiding society. 
In a resolution titled "Condemning Racial Profiling in Traffic Stops" (Police Chief, July 2000), the IACP strangely devotes the first half of the text to defending the use of proactive stops with "whereas intensive law enforcement efforts have been proven to reduce traffic crashes and increase the apprehension of the criminal offender, whereas law enforcement agencies have seized more illegal drugs resulting from traffic enforcement than they have from undercover strategies, and whereas traffic stops, utilizing plain view and consent search annually lead to the interdiction of millions of dollars' worth of illegal substances and stolen property." Only after a series of "whereas" statements justifying and championing aggressive traffic enforcement, does the IACP actually shift to condemn racial profiling. It makes the claim seem half-hearted. Police leadership is defending and supporting the very tactics that have been a primary source of complaints of racial profiling. In many ways, they are giving the same tactic a more neutral name, and ignoring the fact that investigative traffic stops have been the largest contributor of racial disparity. In effect, the IACP is trying to have it both ways by condemning racial profiling but refusing to condemn the tactics that lead into it.

The International Association of Chiefs of Police Highway Safety Committee (IACPHSC) raised the issue of investigatory stops to another level by encouraging departments to patrol in a proactive manner, to aggressively investigate any and all suspicious people and circumstances and to aggressively enforce motor vehicle legislation (IACPHSC 2000).

However, the IACP is not alone in condemning the use of racial profiling while simultaneously defending tactics that encompass its use. The Department of Justice Review (2015) states "the DEA does not collect sufficient data on cold consent encounters to enable it, or the Office of the Inspector General to access whether the encounters are being conducted in and unbiased or effective manner." Less than five pages later in the same Review, the Department of 
Justice state "the DEA collects data as a response to racial profiling accusations. It can be helpful to respond to allegations and conduct an oversight of activities.” The DEA claims that they do not have sufficient data or evidence to access if "cold consent encounters" are being fairly conducted almost directly before stating that they collect data as a response to racial profiling accusations. Though investigatory stops are being called by alternative nomenclatures in all the above examples of policing leaders and government agencies, the tactics remain the same or extremely similar at a minimum. Each of these condemnations of racial profiling has a corresponding defense or endorsement to the use of investigatory stops in official texts. It is as if police leadership have taken Remsberg's admonitions to heart. Don't use the "P" word, but profile. Never say the race of the driver was a factor in stopping them, but feel free to use race as a factor, as long as you can justify it with other factors.

Law enforcement officers are aware that that the methods that are employed for investigatory stops are borderline constitutional. To attempt to aid in preventing further issue with questionable tactics, many training courses, facilities, and books provide advice and training on how to make charges stick (Eagleson 2014). The current reality is that if the officer has a legal justification for the stop, no matter how trivial the reason, it will be acceptable (Epp et al 2014). Since police have begun to enforce and punish offenses regarding public disorder at more frequent rates using minor infractions through broken windows and other community policing techniques, investigatory stops have become the primary tool allowing them to enforce the public disorder violation while providing justification for further investigation (Lombardo 2007). In Police Chief magazine (Ferrell 1999) chiefs and administrators are urged to have officers articulate the dangers that they are facing during vehicle stops and how it affects their decisions. Police officers are told that this articulation can be the difference between their case securing a 
conviction or being dismissed. Another issue of Police Chief provides directions were given to law enforcement officers to include all relevant reports, testimony, and observations in court in a manner that will give the officer legal justification for their actions (Whalen 2002).

Amongst others within the police culture, law enforcement officials develop ways to use the above-mentioned court cases to determine a legal avenue to provide the framework to use vehicle violations to allow temporary detention that may allow for further investigation. An article in PoliceMag (Rutledge 2005), provides police officers step by step details on how they can legally arrest a motorist for minor traffic violations using Atwater v. City of Lago Vista. They continue to provide details on the procedure to order occupants out of the vehicle using the precedent of Pennsylvania v. Mimms. Officers are also provided with the guidance to conduct searches on the passenger compartment of vehicles incident to arrest using the Belton rule.

Urban police chiefs in the New York and New Jersey, as well as the New Jersey Attorney General and other supporters defend the implementation of investigatory stops by attempting to withdraw federal policing agencies from the argument. They further argue that the federal government should not have any jurisdiction over operations of the state and local government (MacDonald 2001). They accuse the Justice Department of persecuting the police. They also fail to mention that the DEA, which is a federal policing and regulatory agency, was responsible for the development and implementation of Operation Pipeline. The same Operation Pipeline that was the origin of the national proliferation of investigatory stops, the largest contributor to racial disparity in traffic stops.

Remsberg, as well as others apply the attempted justification for investigatory stops is if they are conducted in a polite manner they will be accepted by motorists. The methods employed by a good interdiction officer are to be consistently polite, courteous, and systematic in 
the manner every motorist is approached in their practices and the stops will generally be accepted by the motorist and the courts (Haines 2011). Officers are trained to remember the conversation as an interview and not an interrogation, they are told they will get further by being nice and professional (Eagleson 2014). If police use a friendly and conversational tone, most courts will rule that the stop was legal and requests of the officer were voluntary (Wallentine 2009). Officers can increase their amounts of Terry or investigatory stops and substantially reduce the number of complaints if the stops are carried out in a polite manner (Stunts 2002).

The use of politeness and procedural justice can only provide acceptance of investigatory stops to an extent. Officers and leadership are aware that investigatory stops are borderline unconstitutional. Nearly every manual and handbook has a disclaimer or an example of law enforcement personnel overstepping their legal rights during investigatory stops. Unfortunately, many interdiction officers think that they can conduct investigatory stops in any manner they desire until they make a case law regarding their actions (Eagleson 2014). Disclaimers state warnings such as "at no time should any of these tactics replace departmental policies, they are only to be used as suggestions as they will increase your arrests of major criminals" (Eagleson 2014), and "for the integrity and confidentiality of these newly evolved policing tactics, the methods and profiles of contraband smugglers will not be discussed at any point within this manual" (Haines 2011). Though manuals and police leaders have continually denied the use of racial profiling, it is still heavily opposed and mentioned frequently in criminal defense and academic research as being a presently used tactic.

\section{Racial Profiling Litigation and Opposition}

In the 1980s and 1990s police leaders successfully revived and brought legitimacy to investigatory stops and they have gained more use and widespread support than ever before in 
the decades following the above formative times. While some officers may learn these techniques on their own, the tactics are taught and propagated as standard procedure in formal police training to maximize the implementation of investigatory stops while remaining legal in their actions (Sweeney 1996). During the original implementation of Operation Pipeline, the DEA trained 27,000 officers with a component of this training being investigatory stop profiling. This training identified minorities as being more likely to be carrying drugs (Harris 1999). These original 27,000 officers proceeded to train other officers in their individual departments, which began the proliferation of investigatory stops. In 1999, after a large complaints had occurred, the California Task Force on Government oversight conducted an extensive report drawing on interviews, California Highway Patrol records, DEA officials, Highway Patrol officer and canine use records, trial transcripts, and video tapes of Operation Pipeline stops. The report denoted California as one of the most active states in adopting the Operation Pipeline program. Those officers were trained by the DEA to use "indicators." Though the report denies any use of racial profiling, minorities, especially Latinos, were disproportionately affected. Police One (2009) magazine states that officers must maximize contacts on proactive patrol to be able to increase their odds of success regarding interdiction. Police agencies across the United States have transformed the entire process of the investigatory stop conducted in Operation Pipeline into a routine phenomenon.

Though investigatory stops have grown to become a widely used national policing practice, there has consistently been a level of opposition towards these tactics. Racial profiling was widely used and even supported during Operation Pipeline, the use of racial profiling was proposed for this war on drugs tactic from the start. Complaints towards these tactics came shortly thereafter. In 1987, the New Jersey Public Defenders office was receiving a large influx 
of drug cases from the New Jersey turnpike. Civil liberties groups collected more than 200 complaints from minority motorists who were stopped and searched without any justification (Sullivan 1990). In 1990, their office began the first formal investigation on these complaints. Interviews with officers were also showing an increase to a more widespread us of investigatory stops. When confronted with these complaints, police leaders responded with condemnation of racial profiling while simultaneously employing its tactics.

Although Lamberth's study garnered public attention, it was an event that occurred in the spring of 1998 that brought major attention to the use of racial profiling and investigatory stops. A van travelling with four black male occupants that had been pulled over, had allegedly attempted to back into the squad car of two New Jersey State Troopers. The troopers responded to this behavior by shooting three of the four occupants of the vehicle. It was later determined that the occupants of the vehicle were travelling to a basketball tryout and possessed no contraband. A search of their vehicle found only basketball equipment, a bible, and clothing. Law enforcement denied the four occupants medical attention after being shot until they searched their persons. The results of Lamberth's study became widespread public knowledge due to the immense public opposition to profiling in New Jersey following this incident (Harris 2002). On February 28, 1999, an article ran in the Newark Star Ledger featuring comments from the New Jersey Police Superintendent Carl Williams. Williams stated that minorities committed most drug offenses and drug trafficking. These comments served to affirm that New Jersey State Police used racial profiling as a tactic in traffic stops. After firing Superintendent Williams the following day, New Jersey Governor Christie Whitman continued to deny that racial profiling existed in New Jersey traffic stops. 
One underpinning theme is to survive as stated in Remsberg's Street Survival (1986) and The Tactical Edge (1987) books. These books are responsible for the widespread usage of invasive tactics on citizens without provocation. Survival is a false justification for invading the privacy of many innocent citizens. Officers who are conducting investigatory stops often have decided that they were going to conduct an investigation before the actual traffic stop occurs. They can invent a pretext to justify the stop. Though the officer pulls over the motorist under the premise of a traffic stop, investigatory stops are not traffic stops. The main difference between a traffic stop and a pretextual investigatory stop is that the traffic stop has a legitimate traffic safety justification and the investigatory stop will have a low-level violation that may not even have occurred as a justification for the stop (Stuntz 2002). Though they have been trained that it is correct procedure to make traffic stops on questionable traffic violations, law enforcement is well aware of the questionable legality of pretextual investigatory stops.

One possible causation for the continual defense of investigatory stop tactics is that law enforcement officers and authors of interdiction manuals hold the belief that investigatory stops are the solution to winning the drug war across the United States. Haines (2011) states that these stops have a local, regional, and national impact on "murderous criminal activity." Multiple claims are made of the effectiveness of investigatory stops including, "these tactics are the most productive tools regarding the fighting of crime and generation of revenue (2011), "every stop has the potential to find serous criminal conduct" (Remsberg 1995), and "every stop is a potential interdiction" (Eagleson 2014). Drug interdiction manuals hold the common theme that they are having a deterrent effect on the drug problem on a national scale and that it is necessary to apply these techniques universally to win the war on drugs. 
While police leaders never directly acknowledge the continued use of racial profiling in traffic stops, a significant amount of research indicates that the use of profiling continues to be used in investigatory stops. Epp et al (2014) state that the specific, well trained, well entrenched, institutionalized practice of the investigatory stop is the main source of racial disparities in police stops and the reason the victims of pretextual investigatory stops see their use as unfair.

Police leaders have offered several justifications to rationalize racial disparities in traffic stops. Chief among these, police leaders have held that racial disparities in traffic stops are the results of a few officers who participate in the practice of enforcing investigatory stops with the deliberate and intentional use of racial discrimination. However, scholars argue that the racial disparities in traffic data that results from the mass use of investigatory stops are the results of an institutionalized practice and not the result of the actions of a few officers. A 1999 report on Pipeline tactics conducted by the California Highway Patrol (CHP) negates the "few bad apples" argument that police leaders rely on heavily by finding that "individual officers involved in these operations and training programs have been carrying out what they perceived to be the policy of the CHP, the Department of Justice, and the Deukmejian and Wilson administrations. We are not faced with "rogue" officers or individual, isolated instances of wrongdoing. The officers that are involved in these operations have been told repeatedly that they are doing their jobs exactly right. It should be emphasized that this program has been conducted with the approval of CHP management." (Kocieniewski \& Hanley 2000).

However, evidence to the contrary is overwhelming. 
Policing leaders have stated that most drug use can be attributed to minorities which, in turn, causes a disparity in traffic stop numbers. Drug use surveys showed that minorities and whites maintain similar rates of drug consumption (Provine 2007). Due to most police officers being white, implicit intergroup bias occurs in investigatory stops that causes minorities to be targeted more frequently than white people as they are not part of the same intergroup as most police officers (Blair 2001).

Leaders claimed that African Americans commit more traffic infractions causing them to be pulled over more frequently. A study conducted on vehicles on the New Jersey Turnpike (Lamberth 1996), examining the driving behaviors of over 42,000 motorists determined that African Americans and whites violate traffic laws a similar rate. The vehicle code is written in a sufficiently extensive manner for all motorists, including police officers, to be guilty of at least one traffic infraction every occasion that they are operating a motor vehicle. During this study, Lamberth (1996) determined that while $73.2 \%$ if motorists that were arrested were black, only 13.5" of vehicles travelling on the New Jersey Turnpike contained black occupants. Lamberth's study was originally conducted to aid defense lawyers in New Jersey v. Soto (1996). The study produced the unintended result of drawing attention to the use of racial profiling in traffic stops. The source of investigatory stops and the officially guided practice causes officers to act on implicit stereotypes which have been brought about through the institutionalized norm of targeting of minorities (Epp et al 2014).

In Ligon v. New York (2013) a Federal Judge stated that law enforcement are being trained to stop and question the motorist first and then to develop a reasonable suspicion to search their vehicle later. Policies that allow the use of investigatory stops direct officers to be searching for suspicious individuals instead of violations of the law (Epp 2014). 
The entire systematic approach of an early Operation Pipeline investigatory stop is quite similar to that of a modern day investigatory stop. In the earlier manuals, investigatory stops are broken down into basing them off a high number of traffic stops, observing indicators, roadside interviews, earning consent, and conducting vehicle searches. The ideology behind modern investigatory stops nearly identical. Haines (2011) and Eagleson (2014) have included all the above-mentioned tactics and add other components as well in their manuals.

\section{Haines: Inroads: A Working Solution to America's War on Drugs}

Haines (2011) developed and implemented a system that focuses on finding the drug source inroad, making constant contacts along the inroad with suspicious vehicles, using a few basic observations while conducting non-invasive interview questioning, finding indicators, gaining consent, and conducting vehicle searches. In Inroads: A Working Solution to America's War on Drugs, Haines (2011) proposes to "pull over suspected drug dealers and then find means to conduct a legal search of them or their vehicles." These methods have proven to be highly effective in bulk interdiction (Haines 2011). Another method, described in far less detail, involves ordering the occupants out, requesting consent, arresting the driver for a traffic violation, searching the passenger compartment of the vehicle, and conducting an inventory/impound search (PoliceMag 2005). These systematic techniques (excluding the search incident to arrest) to investigatory stops include a similar interview and a clause that states that if you are unable to determine probable cause to ask for consent to search.

Haines (2011) refers to the $3 \%$ er mindset that is essential to the successful criminal patrol and must be used to enhance the investigative aspects of criminal patrol. This $3 \%$ of officers are tasked with enforcing drug interdiction laws that comprise of involvement in $90 \%$ of all criminal offenses, according to Haines (2011). 
Haines (2011) attempts to rationalize the need for more funding for drug interdiction by stating that many more Americans die from drug related deaths $(15,000)$ annually in comparison to $9 / 11(2,973)$ and that anti-terrorism efforts should not be funded to their current extent. It makes Haines irate that only $35 \%$ of police nationwide have access to modern interdiction technology including Desert Snow and Black Asphalt websites that hold information, profiles, trends, and identifiers of drug traffickers. In Haines's opinion, we need to turn the tide to win the war on drugs. The war on drugs is a constant drain on taxpayer money and government resources since we began this battle thirty years ago. Crimes dominate our society that are committed by people under the influence of these "intoxifiers." We spend billions of dollars on treatment and rehabilitation of drug abusers that could be better spent elsewhere (Haines 2011). Every agency should train all officers, not just drug enforcement officers, with the profiles of international trafficking. Haines concludes this portion of his argument with "by employing the teachings of our forefathers illustrated in this training manual across the nation and turning police forces into present day Robin Hoods, we stand a strong chance of discontinuing the railroading, levelling the playing field, and benefitting from substantial forfeiture proceedings. This is a war and we must use war like tactics if we wish to win the war on drugs, in war you seek to inflict the most damage possible."

\section{John Eagleson: It's 4:20 Somewhere}

Training manual author and highway interdiction veteran Lieutenant Corporal James Eagleson (2014) endorses intensely enforcing traffic stops by stating that he frequently wrote several traffic tickets during his lunch break and that he once wrote an entire book of tickets in a single day. Eagleson further claims that he stopped everything that moved and it was nothing for him to write one hundred tickets within a week's time. The methods and techniques used were 
to make interdictions all about making a high volume of traffic stops, find violations and make stops for them, any violation is getting pulled over regardless of the level of severity or risk of safety hazard, and all officers can contact several hundreds of motorists a day while looking for possible criminal indicators. In It's 4:20 Somewhere, Eagleson went as far as making fun of and insulting disgruntled citizens that would call his headquarters to complain about being pulled over for minor traffic infractions that they had never previously been aware of having existed.

Law enforcement personnel can claim a weapon or even a magazine on weapons caused them to fear for their safety, thus providing a reason for the search (Eagleson 2014). Citing multiple indicators gives the officer the opportunity to search under probable cause, and thus, officers must learn to use the tools that they are provided to build probable cause. Safety inspections for commercial vehicles produce a record of the vehicle that can be used to justify future inspections investigations and searches. The use of these safety inspections also provides a legitimate legal avenue to gain entry into commercial vehicles. Eagleson states that he has used safety inspections as probable cause and that it has held up in court on multiple occasions. These measures and investigatory stops in general are not limited to manuals and handbooks. Adding to the proliferation of investigatory stops are schools and online resources for law enforcement.

The "420 Traffic Stop system" was created by Eagleson for commercial vehicle drug interdiction. In this system, the officer receives as much information as possible from dispatch, they interview the driver while attempting to get probable cause through indicators detected during the interview, ask for consent to search the vehicle, make sure that probable cause is "on lock down," and proceed to conduct a search of the vehicle. Though the legality of some 
methods discussed in this manual is questionable, Lieutenant Eagleson achieved career long success using this system (2014).

Modern interviews include all questions that were used in earlier investigatory stop techniques and who owns the vehicle, specific questions regarding traits to cross reference, what the driver does for fun, what they are doing near a known drug source city, are they aware that it is a source city, and numerous similar questions about their trip (Eagleson 2014, Haines 2011). These vehicles are no longer selected by profiles, but by a set of "indicators."

Switch from Profiles to Indicators

Police ceased use of the word profiling and began to make stops on a set of indicators (Harris 2002). The following table of indicators provide an avenue for law enforcement to continue to racially profile and justify their actions by using numerous indicators as reasons why a search had been conducted. In an early Operation Pipeline manual (Simone 1997) and Remsberg's (1995) manual, the following indicators are listed for officers to look for: 
Table 1

Indicators in Early Manuals

\begin{tabular}{ll}
\hline Manuals & Indicators \\
\hline Simone: Kansas Highway Patrol & Luggage discrepancies for trips, atlas/maps, tools and \\
Operation Pipeline Vehicle & markings for concealment, key rings, fast food wrappers, CB \\
Interdiction Manual (1997) & radio, car phone, high odometer, odors, missing handles, \\
& newspapers, police or religious stickers, inoperable windows, \\
& phone cards, non-factory switches, attorney business cards, \\
& expensive vehicles, tinted windows, rental cars, owner not \\
& present, duct tape, packing materials, paint or bondo, \\
& damaged screws, bent panels, signs of drug use, motel \\
& receipts, dilated pupils, blinking, eyes wide open, no eye \\
& contact, closes eyes, squints, facial twitch, dry mouth, \\
& clenched jaw, frowning, twisted mouth, yawning, bites lips, \\
& blushes, turns pale, sweating, shaking, hides hands, points \\
& away, covers eyes, touches face or ears, pats cheeks, touches \\
& hair, covers mouth, fidgets, touches any body part, rubs \\
& hands, scratches, picks lint, touches clothing, can't stay still, \\
& folded arms, leans, tense, \\
& exaggerated movements, restless, taps feet, nausea, \\
& Vomiting, goose bumps, hair stands on end, pulse in neck or \\
& abdomen, says “uh", reluctant, unable to answer, answers \\
with questions, repeats question, asks you to \\
clarify, answers irrelevantly, stutters, sighs, overly friendly \\
asks about you, use qualifiers, doesn't give casual "no" \\
\end{tabular}




\begin{tabular}{|c|c|}
\hline Manual & Indicators \\
\hline $\begin{array}{l}\text { Remsberg: Tactics of Criminal } \\
\text { Patrol (1995) }\end{array}$ & $\begin{array}{l}\text { Abnormal tires, routes, transport vehicles, time of travel, team } \\
\text { driving, rental cars, temporary registration, protective } \\
\text { coloration, multiple state plates, luggage size discrepancies } \\
\text { for trips, map or atlas with inconstancies, tool marks on } \\
\text { screws or doors, no key ring, food wrappers, a car phone, } \\
\text { handles or knobs missing, newspapers from other areas, } \\
\text { police or religious stickers, phone cards, nonoperational } \\
\text { windows, attorney business cards, expensive vehicles, tinted } \\
\text { windows, rental vehicle, 3rd party registration, a wobbly } \\
\text { wheel, a bouncing vehicle, bulging tire, a prolonged stop, } \\
\text { stopping at a green light, packaging materials, motel receipts, } \\
\text { dilated pupils, excessive blinking, no eye contact, squinting, } \\
\text { closed eyes, facial twitches, dry mouth, clenched jaw, } \\
\text { frowning, twistedmouth, red face, a pale face, sweating, } \\
\text { shaking, gesturing, hiding hands, covering eyes, touching } \\
\text { their nose, touching ears, mouth, throat, fidgeting, touching } \\
\text { any body part, scratching, tugging at clothing, picking lint, } \\
\text { leaning, visually locking onto a person or object, tense } \\
\text { movements, restlessness, tapping or moving of the feet, } \\
\text { nausea, vomiting, goosebumps, abdominal pulse, hair stand } \\
\text { on end, tapping or moving of the feet, nausea, vomiting, } \\
\text { goosebumps, abdominal pulse, hair standing on end, } \\
\text { hesitation, reluctance, inability to answer, asking you to } \\
\text { repeat the question, shaky voice, stuttering, making a clicking } \\
\text { sound, sighing, being overly friendly, using qualifiers } \\
\text { ("honestly, truthfully, I believe, believe me"), or any type of } \\
\text { negative response other than a straightforward singular no, air } \\
\text { shocks, improper signage, dirt, multiple masking odors, } \\
\text { unnatural driving maneuvers, repeat vehicles, odors from } \\
\text { body work, car looks lived in, checklists }\end{array}$ \\
\hline
\end{tabular}

Newer manuals and handbooks have the entirety of the previous list of indicators with the combined addition of: 
Table 2

Indicators in Recent Manuals

\begin{tabular}{ll}
\hline Manual & Indicators \\
\hline $\begin{array}{l}\text { Haines: Inroads: A Working } \\
\text { Solution to America's War }\end{array}$ & $\begin{array}{l}\text { All indicators listed in the previous table with the } \\
\text { combined addition of laptops, multiple cellular phones, } \\
\text { on Drugs (2011) }\end{array}$ \\
$\begin{array}{l}\text { Eagleson: It's 4:20 } \\
\text { timemewhere: Professional }\end{array}$ & $\begin{array}{l}\text { unprovoked flight, motorists are not dressed to match the } \\
\text { vehicle, suspicious GPS history, motorist does not look at }\end{array}$ \\
Commercial Vehicle & squad car, American flags, needless accessories, high \\
Interdiction (2014) & $\begin{array}{l}\text { DOT numbers, CB radio on wrong channel, LED lights, } \\
\text { chrome bumpers, toothpicks near the driver, multiple }\end{array}$ \\
& $\begin{array}{l}\text { pairs of sunglasses, graffiti on vehicle, Jesus Malverde } \\
\text { photographs, expensive or lack of mud flaps, small red }\end{array}$ \\
& $\begin{array}{l}\text { lights in corner of windshield, radar detectors, police } \\
\text { scanners, double locks on semi shipments, anything } \\
\text { concerned with Santeria, stretching, store bought moving } \\
\text { boxes, insurance discrepancies, having an improperly } \\
\text { loaded semi, team driving, long hair, fake business cards, } \\
\text { area over lights and signals only clean area on vehicle, } \\
\text { repeating vehicles, and throbbing carotid arteries }\end{array}$ \\
\hline
\end{tabular}

Due to the meticulous lists of indicators that law enforcement personnel have to choose from, it is easy for them to justify racial profiling by omitting its usage and stating their reasonable suspicious or probable cause was that the offender met multiple drug trafficking indicators. Some officers even claim that they can find vehicle indicators and violations on vehicles coming straight off the assembly line (Eagleson 2011). While no explanation has been provided for the original scope of indicators, the current scope has been justified by stating that in the 1970s and 1980s when highway interdiction was being established as being an integral part of drug interdiction, drugs were the only thing that police had to be concerned with (Hawkes 
2012) and now due to technological advancements officers must be more concerned with investigating the interior of vehicles.

While some claim that profiling is still used, most law enforcement officials and personnel deny the usage of race as an indicator in their methods. Haines (2011) claims that traffickers encountered during routine patrol and by the request of drug agencies have interconnecting traits and profiles, none of which are race or ethnicity.

Investigatory Stops, Operation Pipeline, and Drug Interdiction Schools

Police make around 18 million traffic stops in the United States per year (Durose, Smith, and Langan 2005). No other form of direct government control amasses near the amount of these stops in numbers, frequency, proportion of population effected or the degree of coercion that investigatory stops do (Epp 2014).

The emergence of several different schools and resources to train and educate law enforcement personnel on the usage of investigatory stops is an indicator of the prevalence and proliferation of investigatory stops and their status as a routine policing policy. Desert Snow is a one of the largest interdiction training schools and courses that focus on investigatory stops and drug interdiction (Haines 2011). Numerous policing agencies nationwide encourage enrollment in Desert Snow or a similar course and describe it as an essential, high quality training program for all traffic patrol officers.

Charles Remsberg tours the country offering courses through the Street Survival Seminar, James Eagleson instructs interdiction and Pipeline methods through The 4:20 Group school which he owns, as do Charles Haines as a paid contractor for Desert Snow and Ken Wallentine as Vice President and Senior Legal Advisor of Lexipol LLC. Other schools include Criminal Addiction Incorporated, with the motto "Stop it, Search it, Seize it," which focuses on criminal 
and drug interdiction techniques and how to make legal traffic stops, interviews, interviews, indicators, gaining consent, and search and seizure. High Impact Training Solutions (HITS) is a law enforcement training company that focuses on criminal patrol, interdiction, and the use of investigatory stops. The Federal Law Enforcement Training Center teaches criminal interdiction, indicators, interviewing, and consent (FLETC 2017). The highway drug interdiction course taught by Hawkes (2017) centers on investigatory stops, offers to turn officers into "drug finding machines" if they read the article, shows how to look for indicators, teaches the proper court room demeanor, explains the importance of conducting many stops, and then threatens to prosecute any non-law enforcement personnel that attempts to order the materials although the site only asks for first names and an email address on the application to order. The technology, profiles, and indicators in these courses are usually not shared in the recruitment literature for the them. Another interdiction association, the National Criminal Enforcement Association has 4,000 members and holds training and certification for officers that they claim are "vitally necessary" and have been proven to be the most effective (Haines 2011).

Early training manuals state that theses stops are based on high volumes of traffic stops, observation of indicators, roadside interviews, and conducting searches with consent (Simone 1997). Though minor differences exist, more recent handbooks utilize the same tactics in the same order. The original intention of Operation Pipeline in 1984 was to use investigatory stops and profiling as components in the war on drugs that was limited measure both geographically and tactically to aid in the enforcement of border area drug trafficking. Since then the use has become a nationwide phenomenon. Beginning with literature and training such as Remsberg's, officers have been trained to keep their mind open to the possibility that every call or contact has the potential to become a major criminal arrest or a short-term investigation at a minimum 


\section{CHAPTER V: DISCUSSION}

This narrative review determined that racially motivated pretextual investigatory stops have evolved from the original intention as a tactic used in the war on drugs into a routine practice supported in policing literature, police culture, and by policing leaders under the premise of "selling" these intrusive methods. Although the names of investigatory stops and racial profiling have changed, the tactics used are inherently similar if not nearly identical, yet more developed to withstand legal and academic opposition. The use of a geographically limited, profiled traffic stop that was specifically intended to target drug traffickers in the war on drugs has proliferated to a nationwide standard tactic of policing.

Through the examination of training manuals, magazines, articles, and training program solicitation this review has illustrated that the investigatory stop that was used in the early stages of Operation Pipeline has evolved into a more prevalent, complex, and well developed systemic implementation of investigatory stops designed to target motorists, particularly minorities, nationwide. The usage of investigatory stops has transformed from a border area interdiction tactic to catch drug smugglers to an incentive based practice that is universally endorsed and encouraged by government organizations, police, police leaders, and court decisions. The switch from profiles to "indicators," pretextual investigatory stops to "proactive patrol, aggressive patrol, cold consent encounters, Terry stops, intensive traffic patrol, or preventative patrol" appears to be enough to appease those who have opposed the use of investigatory stops and racial profiling.

Further scrutiny of Epp's argument through other sources illustrated that police are aware of the borderline constitutionality of investigatory stops. Numerous manuals and training programs that were reviewed stated precisely what tactics were legally permissible in traffic 
stops, which cases made these tactics legal, ways to write reports, present facts and evidence, and prepare for court to successfully support the legality of the case resulting from the use of an investigatory stop. The officer's actions are not the determining factor in terms of the legality of the traffic stop, the determining factor is the way the officer reports and displays his or her actions to the court.

The underpinning theme is to survive like in Street Survival and The Tactical Edge books. These books are responsible for the widespread usage of invasive tactics on citizens without provocation. Survival is a false justification for invading the privacy of many innocent citizens. Officers who are conducting investigatory stops often have decided that they were going to conduct an investigation before the actual traffic stop occurs. They can invent a pretext to justify the stop. Though the officer pulls over the motorist under the premise of a traffic stop, investigatory stops are not traffic stops. The main difference between a traffic stop and a pretextual investigatory stop is that the traffic stop has a legitimate traffic safety justification and the investigatory stop will have a low-level violation that may not even have occurred as a justification for the stop (Stuntz 2002). Though they have been trained that it is correct procedure to make traffic stops on questionable traffic violations, law enforcement are well aware of the questionable legality of pretextual investigatory stops.

The data accumulation process aided in proving that investigatory stops have exponentially increased in usage since the original implementation and training of 27,000 officers to the extent that they are now a day to day routine tactic in policing. During the early era of investigatory stops involving Operation Pipeline investigatory stops were limited in use and training availability. Currently their use and training capabilities have grown to include nationwide use, numerous private and government conducted training organizations, 
departments, programs, databases, and courses are all readily available to aid in the teaching, continued development, and refining of investigatory stop methods.

Though no investigative stop training literature directly instructs law enforcement personnel to racially profile, the evidence that this practice continues using these stops is irrefutable. When the largest disparity among traffic stops stems from the implementation of investigatory stops, it is obvious that these stops use race as one of their "indicators." Law enforcement continue to hold the position that they do not support racial profiling in any way, yet they continue to endorse and implement the tactic that is most likely to cause racial disparities in arrests and traffic stops.

Policing leaders are providing incentives by rewarding officers to make arrests by conducting investigatory stops through asset forfeiture and the potential for career advancement. These incentives make arrests officers’ primary desired goal (Millazzo and Hansen 1999). Unfortunately, these intrusive stops that are causing the highest arrest numbers are concentrated in investigatory stops that are far more likely to intrude upon innocent African Americans and other minorities (Hallett and Ventresca 2006). A deliberate pattern of intrusion exists before the officer's first contact with the unsuspecting motorist (Epp et al 2014).

Historically, police have been the flashpoint of many racial problems in the United States (Meares 2009). It will be necessary to implement several changes to eliminate the racial disparities and usage of investigatory stops as a primary tool in traffic enforcement. It must be recognized that investigatory stops are counterproductive against crime fighting and divide communities by race. One of the first steps in ceasing the usage of investigatory stops would be to change norms in policing which would require police leaders to acknowledge and promote that investigatory stops cause harm to those who endure them and the larger community (Meares 
2009). Police leaders currently convey the message that investigatory stops work. This message is grossly unbalanced at best and at worse simply false. In the Kansas City Gun Experiment, investigatory stops were intensely conducted on the community. After one generation of investigatory stops, community members distrusted police to the extent that they wouldn't cooperate with information of a gangland shooting at a funeral (Sherman, Shaw, and Rogan 1995). The social cost of distrust toward police and community members becoming more defiant is not worth the short-term benefit of the implementation of investigatory stops.

The practice of investigatory stops is designed to sacrifice the dignity of large amounts of innocent people, minorities in particular, in pursuit of a small number of people who are either dangerous, have contraband, or both. To cease the use of investigatory stops it must be recognized that this is not the results of a few officers, but is an institutionalized practice that is directing officers to stop suspicious looking motorists and that it will trigger social cognitions that can result in the triggering of minorities (Epp et al 2014).

Police leaders should return to the professional norm of not stopping drivers unless justified by clear evidence of criminal behavior. The standard of proof should be returned to an objective probable cause that is not determined form and exhaustingly extensive list of "indicators." Unfortunately, decisions amongst high courts will be necessary to curtail the usage of investigatory stops due to the endorsement and institutionalization of these stops by police and policing leaders. To effectively achieve continued, long term success in reducing crime rates, scattershot usage of investigatory stops needs to be replaced by targeted intervention measures. It is easier to stop a few citizens that police know are going to cause trouble than to attempt to stop them all with the hopes of catching a few. 


\section{CHAPTER VI: CONCLUSION}

The use of investigatory stops has been the cause of racial disparity in traffic stop rates, arrest rates, and incarceration rates nationwide. The issue of the continual use of these stops, in combination with attempts to conceal key characteristics of them from the public must be addressed. It is not a matter of sufficient evidence existing but of drawing ample attention to the effects of investigatory stops.

After further scrutiny, through the examination of numerous journal articles, training manuals, interdiction course advertisement and solicitations, and government reports it has been confirmed that the tactics used for investigatory stops that were originally intended for use in the war on drugs on a limited basis, have evolved into a routine day to day practice using techniques that are supported in policing literature, in police culture, and by police leaders under the false premise of "selling" the invasion of motorists privacy as good and effective police work. Excluding Epp, there are minimal amounts of research on investigatory stops that focus on multiple studies. The intrusive methods of investigatory stops have been developed and strengthened over the course of the last thirty years and very few have brought the issue to public attention. The intention of this narrative review was to explore the ongoing intrusion of privacy, continual use of racial profiling, and the attempted concealment of racist/unethical practices by police, the government, and policing leaders through the implementation of pretextual investigatory stops. These methods are an obvious intrusion of privacy and violation of the rights of millions of citizens annually, the majority of them minorities. 


\section{REFERENCES}

Armacost, B. E. (2009). Arizona v Gant: Does it Matter? The Supreme Court Review, 2009.

Banks, J. (2016). Thin Blue Lines: How Pretextual Stops Undermine Police Legitimacy. Case Western Reserve Law Review. Volume 66, Issue 4.

Bernardo, W., Nobre, M., Jatene F., (2004). A Clinical Practice Based on Evidence: Looking for Evidence: Part two, Looking for Sources of Evidence and Information. My Solutions, 50(1):1-9.

Bernstein, S., (1990). Fourth Amendment- Using the Drug Courier Profile to Fight the War on Drugs. Journal of Criminal Law and Criminology, Volume 80.

Blair, I., (2001) Implicit Stereotypes and Prejudice. Princeton Symposium on the Legacy and Future of Social Cognition: p. 359-74.

Brown, M., (2001). Criminal Investigation: Law and Practice, $2^{\text {nd }}$ ed. Boston ButterworthHeinemann, 2001.

Buckman, J. (2001, September 21) Personal Interview on Profiling with Harris, David.

Campbell Collaboration (2001). Campbell Collaboration Guidelines. Retrieved January 15, 2017 from www.campbellcolllaboration.org

Cannon, Angie. “DWB: Driving while black.” U.S. News \& World Report Mar 1999.U.S. News \& World Report.

Cespedes-Yaffar, L., Dhanak, S., Stephenson, A., (2010) U.S. v. Mendenhall, U.S. v. Sokolow, and the Drug Courier Profile Evidence Controversy. Cornell University Law Journal.

Cole, D., (2000). No Equal Justice: Race and Class in the American Criminal Justice System. The New Press, New York.

DEA, \& New Mexico State Police. (1986). Videocassette. Tactics and Techniques of Highway 
Traffic Stop Drug Interdiction. Financed by DEA.

Eagleson, J. (2014) It's 4:20 Somewhere: Professional Commercial Vehicle Interdiction. Create Space Independent Publishing.

Epp, C., Maynard-Moody, S., Haider-Markel, D., (2014). Pulled Over: How Police Define Race and Citizenship. Chicago Series in Law and Society.

Feder, J. CRS Report for Congress. April 16, 2012.

Federal Law Enforcement Training Centers, (2017). Patrol Criminal Interdiction Training Program.

Ferrell, J. "Are More Traffic Stops and Fewer Citizen Complaints Mutually Exclusive?” Police Chief, July 1999, 35-38.

Gamrath, C. The Law of Pretext Stops Since Whren v. United States. Illinois Bar Journal, October 1997.

Georges, W. (2000) Traffic Safety Strategies Yield Tangible Benefits. Police chief, June 2000 p. 53-57.

Gizzi, M. C., \& Curtis, R. C. (2016). The Fourth Amendment in Flux: The Roberts Court, Crime Control, and Digital Privacy.

Glantz, C., (1997). Could this be the End of the Fourth Amendment Protections for Motorists? Journal of Criminal Law and Criminology. Volume 87, Issue 3.

Haines, C., (2011) Inroads: A Working Solution to America's War on Drugs. Authorhouse Publishing.

Harris, D. (2002). Profiles in Justice: Why Racial Profiling Cannot Work. The New Press.

Harris, D. Racial Profiling on our Nation's Highways. Driving While black. ACLU 1999. Hawkes, A. Lt., (2012). Highway Interdiction: It's not Just about Drugs Anymore. Police One 
Magazine. Published March 28, 2012.

Hecker, S. (1997). Race and Pretextual Traffic Stops: An Expanded Role for Civilian Review Boards. Columbia Human Rights Law Review 28(3), 551-604.

Hvidston, P. (2014). Arrest Reasonableness: The United States Supreme Court Permits Investigative Stops Based on Anonymous Tips Arrest. (2014). North Dakota Law Review, 90623.

International Association of Chiefs of Police. "Condemning Racial and Ethnic Profiling in Traffic Stops. Resolution Adopted at $106^{\text {th }}$ Conference. Police Chief July 2000, 19. International Association of Chiefs of Police. "Ensuring Professional Traffic Stops: Recommendations form the First IACP Forum on Professional Traffic Stops.: Police Chief, July 1999, 15-23.

International Association of Chiefs of Police Highway Traffic Safety Committee. "Looking Beyond the License Plate Program Underscores Diligent Police Work." Police Chief, July 2000, 70-72.

Johnson, K. R. (2016). Doubling Down on Racial Discrimination: The Racial Disparate Impacts of Crime-Based Removals. Case Western Reserve Law Review, 66(4), 993. P. 1004

Kamulu, N., (2016) African Americans and Racial Profiling by U.S. Law Enforcement: An Analysis of Police Traffic Stops and Searches of Motorists in Nebraska, 2002- 2007. African Journal of Criminology and Justice Studies: AJCJS, Vol.9, Issue 1.

Kirkevold, M. (1997). Integrative Nursing Research- an Important Strategy to Further the Development of Nursing Science and Practice. Journal of Advanced Nursing 25, 977984.

Kocieniewski, D., \& Hanley, R. "Racial Profiling Routine, New Jersey Finds.” New York Times 
28 November 2000.

Kocieniewski, D., "New Jersey Argues that United States Wrote the Book on Racial Profiling." New York Times, 29 November 2000.

Lamberth, J., (1996). Revised Statistical Analysis of the Incidence of Police Stops of Black Drivers/Travelers on the New Jersey Turnpike Between Interchanges 1 and 3 form the Years 1988 to 1991 , at 2.

Law Officer, Tactics, Technology, Training., (2016). Supreme Court Rules Police may use Evidence Found After Illegal Stops. Published 20, 2015.

Law Officer, Tactics, Technology, Training. (2009). Published May 13, 2010.

Lawton, M.M, (2008). The Road to Whren and Beyond: Does the "Would Have" Test Work?

Lawton, M. M. (2016). State Responses to the Whren Decision. Case Western Reserve Law Review, 66(4), 1039.

Levit, J. (1996). Pretextual Traffic Stops: United States v. Whren and the Death of Terry v. Ohio. Loyola University Chicago Law Journal. Volume 28, Issue 1, 1996.

Lombardo, R., \& Lough, T. (2007). Community Policing: Broken Windows, Community Building, and Satisfaction with the Police. Police Journal, 80(2), 117-140.

Macdonald, H, “The Myth of Racial Profiling” City Journal 11, no. 2 (Spring 2001)

Marcou, Lt. D., (2009) Improving Proactive Criminal Interdiction. Police One, October 2009.

Maria, G., Booth, A., (2009) Salford Centre for Nursing, Midwifery and Collaborative Research, University of Salford, Salford, UK, School of Health and Related Research, University of Sheffield, Sheffield, UK.

Meares, T., \& Harcourt, B., (2009). Randomization and the Fourth Amendment. University of Chicago Law Review: p. 809-877. 
Murgado, A. (2012). Police Magazine. Drug Interdiction for Patrol: Know what to: look for on Traffic Stops to Make an Impact on the Drug Trade. https://www.fletc.gov/training-program/patrol-criminal-interdiction-training-program on December 22, 2016.

O'Neill, T. P. (2009). Vagrants in Volvos: Ending Pretextual Traffic Stops and Consent Searches of Vehicles in Illinois. Loyola University Chicago Law Journal 40(4), 745-780.

PCITP., (2016). Patrol Criminal Interdiction Training. Accessed from https://www.fletc.gov/patrol-criminal-interdiction-training-program/patrol-criminalinterdiction-training-program on March 23, 2016.

Pendleton, Hon. A.F. Judges Handbook on Motor Vehicle Stops. Minnesota Judicial Training Update. June 15, 2012.

Provine, D., (2007). Unequal Under Law: Race in the War on Drugs. Chicago: University of Chicago Press.

Pulliam, A. (1994). Developing Meaningful Fourth Amendment Approach to Automobile Investigatory Stops. Vanderbilt Law Review 47(2), 477-534.

Remsberg. C., (1987). Street Survival: Tactics for Armed Encounters. Calibre Press, Inc. Remsberg, C., (1986) Tactical Edge: Surviving High Risk Patrol. Calibre Press, Inc. Remsberg, C., (1995). Tactics for Criminal Patrol: Vehicle Stops, Drug Discovery, \& Officer Survival. Calibre Press, Inc.

Runge, J., (2002) The Role of Traffic Law Enforcement in Homeland Security. Police Chief October 2002 p. 92-97.

Rutledge, D. (2005). Investigative Traffic Stops: Stopping a Suspicious Person on the Pretext Of a Traffic Violation is Perfectly Legal... as Long as you have Probable Cause. Police; 
The Law Enforcement Magazine, September 2005.

Sallah, M., O'Harrow Jr., R., Rich, S., Silverman, G., Stop and Seize: Aggressive Police Take Hundreds of Millions of Dollars from Motorists Not Charged with Crimes. Washington Post. September 6, 2014.

Sherman, L., Shaw, J., \& Rogan, D. (1995). The Kansas City Gun Experiment. National Institute of Justice. January 1995.

Sievers, M., (2014). State v. Ochoa: The End of Pretextual Stops in New Mexico? Mexico Law Review.

Simone, K. (1997) Operation Pipeline Highway Interdiction Manual. Kansas Highway Patrol.

Stuntz, William, J. (2002) Local Policing after the Terror. Yale Law Journal III, no. 8 (June 2002): 2137-94.

Stuntz, William J. (1998). Race, Class, and Drugs. Columbia Law Review 98: 1795, 1799, 1821.

Sullivan, P. (1990). Attitude Structure of Different Ethnic Age Groups Concerning Police. Journal of Criminal Law and Criminology 78: 177-96.

Sweeney, Earl M., "Combating Crashes and Crime through Professional Traffic Stops." Police Chief, July 1999, 39-42.

Taylor, Stuart. "Racial Profiling: The Liberals Are Right.” The National Journal, Apr1999. The National Journal. Online. Nexis.

US Department of Justice. Review of the Drug Enforcement Administration's Use of Cold Consent Encounters at Mass Transportation Facilities. January 2015.

Wallentine, K., (2009). Current Legal Issues in Traffic and Investigatory Stops. 2009 Justice Court Spring Conference. 
Webb, Gary. "DWB.” Esquire April 1999. Esquire. Online. Nexis.

Whalen, M. "Supreme Court Rulings Acknowledge Practical Considerations of Law Enforcement." Police Chief. April 2002, II.

Wilson, J. Q., \& Boland, B., (1978). Dangerous Frames: How Ideas About Race and Gender Shape Public Opinion. Law \& Society Review 12, no. 3, p. 367-390. 


\section{APPENDIX A: COURT CASES}

\section{Court Cases}

Arizona v. Gant (2009)

Arizona v. Johnson (2009)

Atwater v. Lago Vista (2001)

Brendlin v. California (2007)

Carroll v. United States (1925)

Chambers v. Maroney (1970)

Chimel v. California (1969)

Delaware v. Prouse (1979)

Draper v. United States (1959)

Florida v. Harris (2013)

Herring v. United States (2009)

Katz v. United States (1967)

Maryland v. Wilson (1997)

Michigan v. Sitz (1990)

Navarrete v. California (2014)

New Mexico v. Ochoa (2009)

New York v. Belton (1981)

Ohio v. Robinette (1996)

Olmstead v. United States (1928)

Pennsylvania v. Mimms (1977)

Rodriguez v. United States (2015) 
Terry v. Ohio (1968)

Thornton v. United States (2004)

United States v. Hernandez-Cuartas (1991)

United States v. Lefkowitz (1932)

United States v. Leon (1984)

United States v. Sokolow (1989)

Virginia v. Moore (2008)

Whren v. United States (1996) 


\section{APPENDIX B: LIST OF SOURCES ANALYZED}

Similar to Epp et al., the narrative review will first contain an in-depth exploration of Remsberg's Street Survival (1995) training manual to discover the ways police have transformed the investigatory stop, a tool primarily intended for the war on drugs, into a tactic which is used on all types of motorists daily. It will further examine the support or disapproval of racial profiling or efforts to conceal the use of profiling under different nomenclatures. This manual draws from his other training manuals: Street Survival (1987) and Tactical Edge (1986).

Following the in-depth analysis of the Remsberg manual, the training manuals In Roads: A Working Solution to America's War on Drugs by Charles Haines (2011), and It's 4: 20 Somewhere: Professional Commercial Vehicle Interdiction by James Eagleson (2014). These training manuals will also be subject to a meticulous review to attempt to determine if other sources further support the argument of police leadership and administration have been disingenuous in the combatting of racial profiling through the continuance of the same practices while calling them different names.

Following the examination of the above book formatted manuals, this study will focus on the encouragement in the use of investigatory stops and racial profiling in investigatory stops through the thorough review of a Kansas Highway Patrol Operation Pipeline Passenger Vehicle Drug Interdiction Handbook (Simone 1997). This handbook should provide information on early investigatory stop practices and early usages in profiling as well as the terminology used, if any, in racial profiling.

To determine differences in official policing manuals from Operation Pipeline to current investigatory manuals an extensive review of Minneapolis Police Department's Investigatory Stop Documentation Review (2015) will be conducted. By reviewing this manual, this study 
attempts to discover disparities or similarities in current approval patterns, prevalence, profiling, and terminology from the timeframe in which investigatory stops originated through their status.

Policing magazine were examined to provide an examples of police culture regarding investigatory stops. These articles include excerpts from Police Chief (Ferrell July 1999, Georges June 2000, International Association of Chiefs of Police July 1999/July 2000, Runge October 2002, Sweeney July 1999, Whalen April 2002), Police One Magazine (Hawkes March 2012, Marcou October 2009, Murgado December 2012), and Police; The Law Enforcement Magazine Rutledge September 2005).

To illustrate police leadership and governmental support of investigatory stops literature which that was analyzed included; review on DEA Use of Cold Consent Encounters at Mass Transportation Facilities (US DOJ 2015), The Kansas City Gun Experiment (National Institute of Justice 1995), and CRS Report for Congress (Feder 2012).

The current proliferation and abundance of investigatory stops was demonstrated through the literature from classes and programs using investigatory stop techniques Desert Snow (2017), Black Asphalt (2017), Federal Law Enforcement Training Center (2017), High Impact Training Solutions (2013), Law Officer; Tactics, Technology, and Training (2009, 2016), and Patrol Criminal Interdiction Training (2016). 